\title{
Kinetic determinations of trace element bioaccumulation in the mussel Mytilus edulis
}

\author{
Wen-Xiong Wang ${ }^{1}$, Nicholas S. Fisher ${ }^{1, *}$, Samuel N. Luoma ${ }^{2}$ \\ 'Marine Sciences Research Center, State University of New York, Stony Brook, New York 11794-5000, USA \\ ${ }^{2}$ MS 465, US Geological Survey, 345 Middlefield Road, Menlo Park, California 94025, USA
}

\begin{abstract}
Laboratory experiments employing radiotracer methodology were conducted to determine the assimilation efficiencies from ingested natural seston, the influx rates from the dissolved phase and the efflux rates of 6 trace elements (Ag, Am, Cd, Co, Se and $\mathrm{Zn}$ ) in the mussel Mytilus edulis. A kinetic model was then employed to predict trace element concentration in mussel tissues in 2 locations for which mussel and environmental data are well described: South San Francisco Bay (California, USA) and Long Island Sound (New York, USA). Assimilation efficiencies from natural seston ranged from 5 to $18 \%$ for $\mathrm{Ag}, 0.6$ to $1 \%$ for $\mathrm{Am}, 8$ to $20 \%$ for $\mathrm{Cd}, 12$ to $16 \%$ for $\mathrm{Co}, 28$ to $34 \%$ for Se, and 32 to $41 \%$ for $Z n$. Differences in chlorophyll a concentration in ingested natural seston did not have significant impact on the assimilation of $\mathrm{Am}, \mathrm{Co}$, Se and $\mathrm{Zn}$. The influx rate of elements from the dissolved phase increased with the dissolved concentration, conforming to Freundlich adsorption isotherms. The calculated dissolved uptake rate constant was greatest for $\mathrm{Ag}$, followed by $\mathrm{Zn}>\mathrm{Am} \approx$ $\mathrm{Cd}>\mathrm{Co}>\mathrm{Se}$. The estimated absorption efficiency from the dissolved phase was $1.53 \%$ for Ag, $0.34 \%$ for Am, $0.31 \%$ for $\mathrm{Cd}, 0.11 \%$ for $\mathrm{Co}, 0.03 \%$ for Se and $0.89 \%$ for $\mathrm{Zn}$. Salinity had an inverse effect on the influx rate from the dissolved phase and dissolved organic carbon concentration had no significant effect on trace element uptake. The calculated efflux rate constants for all elements ranged from 1.0 to $3.0 \% \mathrm{~d}^{-1}$ The route of trace element uptake (food vs dissolved) and the duration of exposure to dissolved trace elements ( 12 h vs 6 d) did not significantly influence trace element efflux rates. A model which used the experimentally determined influx and efflux rates for each of the trace elements, following exposure from ingested food and from water, preducted concentrations of $\mathrm{Ag}, \mathrm{Cd}$, Se and $\mathrm{Zn}$ in mussels that were directly comparable to actual tissue concentrations independently measured in the 2 reference sites in national monitoring programs. Sensitivity analysis indicated that the total suspended solids load, which can affect mussel feeding activity, assimilation, and trace element concentration in the dissolved and particulate phases, can significantly influence metal bioaccumulation for particlereactive elements such as Ag and Am. For all metals, concentrations in mussels are proportionately related to total metal load in the water column and their assimilation efficiency from ingested particles. Further, the model predicted that over $96 \%$ of Se in mussels is obtained from ingested food, under conditions typical of coastal waters. For $\mathrm{Ag}, \mathrm{Am}, \mathrm{Cd}, \mathrm{Co}$ and $\mathrm{Zn}$, the relative contribution from the dissolved phase decreases significantly with increasing trace element partition coefficients for suspended particles and the assimilation efficiency in mussels of ingested trace elements; values range between 33 and $67 \%$ for $\mathrm{Ag}, 5$ and $17 \%$ for $\mathrm{Am}, 47$ and $82 \%$ for Cd, 4 and $30 \%$ for Co, and 17 and $51 \%$ for $\mathrm{Zn}$.
\end{abstract}

KEY WORDS: Bioaccumulation Kinetic modeling - Metals - Mussels Americium Cadmium Cobalt. Selenium Silver Zinc

\section{INTRODUCTION}

Contamination of coastal waters by toxic chemicals is a major concern in many parts of the world. Measurements of ambient chemical concentrations in water or sediment have limited value for assessing the

- Addressee for correspondence

E-mail:nfisher@ccmail.sunysb.edu potential impacts of contamination because these environmental pools may not represent the biologically available fraction. Consequently, marine mussels are employed throughout the world as biological monitors of coastal contamination. Field and laboratory studies have identified the attributes of suitable biomonitors (Phillips 1980) and the biological and abiotic factors that affect trace element bioaccumulation in such organisms (Phillips 1980. Bryan 1984). In the United 
States, the National Status and Trends (NS\&T) Program monitors trace element concentrations in mussels and oysters from coastal regions (O'Connor 1992, 1996 , O'Connor et al. 1994) in order to delineate contamination trends over large temporal and spatial scales.

The assumption in biomonitoring is that bivalves accumulate trace metals in direct proportion to ambient concentrations. There is evidence that this assumption is generally met for most metals (Phillips 1980). However, environmental conditions (such as suspended particle loads) and metal concentrations can vary in space and time on scales not easily measured in monitoring programs (e.g. spills, seasonal variability, locally contaminated sites such as near industrial outfalls) (Luoma et al. 1990). Models are necessary to supplement monitoring and predict bioaccumulation across this variety of conditions. In addition, it is difficult to unambiguously explain trends identified, for example, by NS\&T, without a mechanistic understanding of the rates and routes of bioaccumulation. Models can help identify pathways and the most important processes responsible for contaminant bioaccumulation. Accurate bioaccumulation models are probably necessary to establish the key parameters for water quality criteria and provide an objective basis for risk assessment (DiToro et al. 1991, Luoma \& Fisher 1996).

In the marine environment, trace elements are partitioned between aqueous and particulate phases, as controlled by processes such as adsorption/desorption and precipitation/dissolution. Marine bivalves are exposed to trace elements through the dissolved phase and ingestion of particulate matter. Element bioavailability is determined by geochemical behavior in both phases, as well as the biological factors that determine metal interactions with the animals. The relative importance of dissolved and particulate uptake vectors in trace element accumulation in aquatic animals has not been well characterized. Traditionally, this has been quantified by. (1) direct experimental separation of dissolved and particulate uptake; (2) indirect mass balance method to calculate the contribution of each uptake source; and (3) comparison of tissue distribution observed in the laboratory with observations in nature (Luoma 1989). Most of these experimental approaches have 2 major disadvantages: (1) experimental conditions often do not reflect those prevailing in natural waters, and (2) no single relationship is likely to be appropriate for all field conditions (therefore experiments are often not predictive).

Another approach to estimate bioavailability relies on bioconcentration factors, which relate metal concentration in the animals to a known ambient metal concentration. Equilibrium of metal partitioning between animal and aqueous environment is rarely met in the laboratory; thus, it has been difficult to predict bioconcentration factors in the field from laboratory studies that assume equilibrium conditions. Recently, laboratory studies have focused on the kinetics of toxicant accumulation and depuration in aquatic animals, and several kinetic bioaccumulation models have been developed (Breck \& Bartell 1988, Landrum et al. 1992, Newman 1995). Kinetic models have large data requirements, but the approach is not constrained by assuming that toxicant accumulation is by constant exposure or governed by thermodynamic equilibria (Landrum et al. 1992, Luoma \& Fisher 1996). Kinetic models have been successfully applied to study contaminant bioaccumulation in marine bivalves when measurements are limited to a few important physiological parameters, including influx rate from dissolved phase, assimilation efficiency (AE) from ingested food particles, and efflux rates. For example, Boese et al. (1990) demonstrated that tissue concentrations of hexachlorobenzene in the clam Macoma nastata predicted from this model were very close to the observed tissue concentrations during a short-term experiment. Luoma et al. (1992) showed that the tissue concentration of Se predicted from this model was comparable to the actual Se concentration found in Macoma balthica in San Francisco Bay (California, USA).

In this paper, physiological parameters necessary to construct a kinetic trace element bioaccumulation model for mussels are identified and quantified. Parameters include trace element AEs from ingested natural seston, dissolved influx rates and efflux rates. Some of the factors affecting these processes are also considered. The model is then employed to predict trace element concentrations in mussel tissues under environmental conditions characteristic of San Francisco Bay and Long Island Sound (New York, USA), and the predicted concentrations are compared to concentrations observed in mussels in those locations. The goals of the modeling are to quantitatively characterize the processes responsible for metal accumulation in mussels in these and other estuarine systems, and to separate the contributions of different uptake vectors (dissolved vs particulate) to the overall metal uptake in mussels. Among the 6 trace elements studied in this paper (Ag, Am, Cd, Co, Se and $\mathrm{Zn}$ ), elevated concentrations of $\mathrm{Ag}, \mathrm{Cd}, \mathrm{Se}$ and $\mathrm{Zn}$ are common in many coastal waters, whereas radioisotopes of Am and Co are important components of some nuclear wastes discharged into some coastal waters (Park et al. 1983, Mount et al. 1994). Of these elements, Co, Se, and Zn are biologically essential. Ag is a Class B (sulfur-seeking) metal, Am is a Class A (oxygen-seeking) metal, and the others are borderline metals (Nieboer \& Richardson 1980). 


\section{MATERIALS AND METHODS}

Mussels Mytilus edulis of 3.0 to $3.5 \mathrm{~cm}$ shell length were collected from Oldfield, Long Island Sound, a location with no known elevated metal concentration in seawater ( $O^{\prime}$ Connor 1992). Mussels were acclimated in $10 \mathrm{l}$ of aerated seawater $\left(28 \%, 15^{\circ} \mathrm{C}\right)$ for 1 wk prior to experiments. During these periods they were continuously fed the diatom Thalassiosira pseudonana at a daily ration of about $2 \%$ of their tissue dry weight.

Trace element assimilation from natural seston. Water samples were collected from Stony Brook Harbor (SB) during the spring phytoplankton bloom (March 4 and 11, 1995). The chlorophyll a (chl a) concentrations in these waters were determined (Parsons et al. 1984) and phytoplankton abundance and composition were quantified microscopically. The seawater was first passed through a $160 \mu \mathrm{m}$ nylon mesh to remove large particles and grazers, and then filtered through a $3 \mu \mathrm{m}$ polycarbonate membrane. The particles (in the size range 3 to $160 \mu \mathrm{m}$ ) retained on the membrane were resuspended and concentrated into 2 flasks containing $120 \mathrm{ml}$ of $0.2 \mu \mathrm{m}$ filtered seawater $(28 \%)$

Two groups of resuspended seston were then radiolabeled for $36 \mathrm{~h}$ with ${ }^{241} \mathrm{Am}+{ }^{75} \mathrm{Se}+{ }^{65} \mathrm{Zn}$ and ${ }^{110 \mathrm{~m}} \mathrm{Ag}+$ ${ }^{109} \mathrm{Cd}+{ }^{57} \mathrm{Co}$, respectively, during which the sealed flasks were placed in the dark on a spinning wheel (2 rpm) to diminish aggregation of seston and prevent settling (Lee \& Fisher 1994). Radioisotope additions were $37 \mathrm{kBq}\left(320 \mathrm{nM}\right.$ ) for ${ }^{110 \mathrm{~m}} \mathrm{Ag}$ (in $0.1 \mathrm{~N} \mathrm{HNO}_{3}$ ), 37 $\mathrm{kBq}(120 \mathrm{nM})$ for ${ }^{241} \mathrm{Am}$ (in $\left.3 \mathrm{~N} \mathrm{HNO}_{3}\right), 74 \mathrm{kBq}(43 \mathrm{nM})$ for ${ }^{109} \mathrm{Cd}$ (in $0.1 \mathrm{~N} \mathrm{HCl}$ ), 18 to $37 \mathrm{kBq}$ (8.6 to $1.7 .2 \mathrm{pM}$ ) for ${ }^{57} \mathrm{Co}$ (in $0.1 \mathrm{~N} \mathrm{HCl}$ ), $74 \mathrm{kBq}\left(4.1 \mathrm{nM}\right.$ ) for ${ }^{75} \mathrm{Se}$ $\left(\mathrm{Na}_{2} \mathrm{SeO}_{3}\right.$, in distilled water), and $74 \mathrm{kBq}(100 \mathrm{nM})$ for ${ }^{65} \mathrm{Zn}$ (in $0.1 \mathrm{~N} \mathrm{HCl}$ ). Before the additions of radioisotopes, microliter amounts of $0.5 \mathrm{~N}$ Suprapur $\mathrm{NaOH}$ were added to maintain the $\mathrm{pH}$ of the seawater at 8.0.

At the end of radiolabeling, the seston was collected by filtration onto $3 \mu \mathrm{m}$ polycarbonate membranes and resuspended into unlabeled $0.2 \mu \mathrm{m}$ filtered seawater Five individual mussels were placed in $800 \mathrm{ml}$ of $0.2 \mu \mathrm{m}$ filtered seawater held in a polypropylene beaker. Every 5 min radioactive seston was added at a concentration of $1.0 \mathrm{mg} \mathrm{l}^{-1}$. Because mussels essentially ingested all particles during the $30 \mathrm{~min}$ radioactive feeding period, an average ingestion rate of $1.9 \mathrm{mg}$ $\mathrm{h}^{-1}$ was achieved for each mussel. There was little variation in ingestion activity among different individual mussels. After the radioactive feeding, mussels were rinsed and radioassayed non-destructively (described below). Counting times were $1.5 \mathrm{~min}$ for each mussel. Mussels were subsequently placed individually into $240 \mathrm{ml}$ polypropylene beakers, each containing $150 \mathrm{ml}$ of seawater, and held within an enclosed recirculating seawater system (described in Wang et al. 1995). The water flow rate through each mussel chamber was about $2 \mathrm{lh}^{-1}$

Previous experimentation indicated that mussels complete their digestion and assimilation of trace elements within $72 \mathrm{~h}$ (Wang et al. 1995). Consequently, mussels were depurated of the ingested radiolabeled materials for $4 \mathrm{~d}$, during which they were continuously fed unlabeled diatom Thalassiosira pseudonana cells at an approximate daily ingestion rate of $3 \%$ of their tissue dry weight. Radioactivities of mussels were counted at time intervals of 4 to $12 \mathrm{~h}$. Feces were collected throughout the depuration period and radioassayed. Because egestion of radiotracers occurred primarily within the first $12 \mathrm{~h}$ of depuration, feces were collected at time intervals of 1 to $3 \mathrm{~h}$ and later extended to every 4 to $12 \mathrm{~h}$.

Aliquots of radiolabeled seston were analyzed to determine the cytoplasmic distribution of radiotracers, as described in Fisher et al. (1983b). Seston was collected on a $1 \mu \mathrm{m}$ polycarbonate membrane and washed for $2 \mathrm{~min}$ with $10 \mathrm{ml}$ of $1 \mathrm{mM}$ EDTA to remove surface bound metals. The seston was then resuspended into distilled water $(\mathrm{pH}=7.0)$ and frozen. Microscopic examination confirmed that all algal cells were broken apart by this treatment. Cell debris was centrifuged sequentially at different speeds to fractionate the cytological components of radiotracers $(8000 \times g$ for $15 \mathrm{~min}$, $20000 \times g$ for $15 \mathrm{~min}$ and finally $100000 \times \mathrm{g}$ for $20 \mathrm{~min}$ ). The final supernatant was considered to contain the cytoplasmic fraction.

Trace element influx rate from the dissolved phase. Dissolved influx rate describes the rate at which a trace element in the dissolved phase is accumulated by the mussel. Short exposures are employed to measure gross influx rates, the goal being to obtain a tissue concentration that is minimally influenced by efflux. Further, a mussel's ventilating activity will decline in the absence of food particles, and the influx rate may therefore be underestimated. Short exposures can overcome this difficulty. In our experiments, mussels were therefore exposed to dissolved trace elements for $2 \mathrm{~h}$, during which the ventilation rate does not decline appreciably due to the absence of food particles (e.g. Widdows \& Hawkins 1989).

Prior to these experiments, mussels were continuously fed with the diatom Thalassiosira pseudonana for $7 \mathrm{~d}$. They were then placed individually into $500 \mathrm{ml}$ of $0.2 \mu \mathrm{m}$ filtered seawater (collected $8 \mathrm{~km}$ off Southampton, Long Island) with different dissolved concentrations of trace elements (stable plus radioisotope, with the exception of ${ }^{241} \mathrm{Am}$ ). The experimental temperature was $15^{\circ} \mathrm{C}$ and the salinity of the experimental water was adjusted to $28 \%$. There were 8 replicate individuals for each treatment. Stable trace element 
was added so that the lowest concentration was 3 to 5 times its typical concentration in uncontaminated coastal waters (with the exception of $\mathrm{Ag}$ and ${ }^{241} \mathrm{Am}$ ). Thus, concentrations ranged from 0.2 to $100 \mathrm{\mu g} \mathrm{l}^{-1}$ for $\mathrm{Ag}$ (in $\mathrm{AgNO}_{3}$ ); 0.1 to $10 \mu \mathrm{gl}^{-1}$ for $\mathrm{Cd}$ (in $\mathrm{CdCl}_{2}$ ), Co (in $\mathrm{CoCl}_{2}$ ) and $\mathrm{Se}$ (in $\mathrm{Na}_{2} \mathrm{SeO}_{3}$ ), 0.5 to $300 \mu \mathrm{gl}^{-1}$ for $\mathrm{Zn}$ (in $\mathrm{ZnCl}_{2}$ ); and 9.4 to $247 \mathrm{ng} \mathrm{l^{-1 }}$ for ${ }^{241} \mathrm{Am}$. Radioisotopes were allowed to equilibrate with stable elements overnight prior to contact with the mussels.

Any feces egested by the mussels during the $2 \mathrm{~h}$ uptake period was immediately pipetted out of the water to minimize fecal scavenging of trace elements. The water was gently stirred every $10 \mathrm{~min}$. After $2 \mathrm{~h}$ of uptake, mussels were rinsed and dissected. Radioactivities of tissues were measured with an LKB Compugamma counter (described below). The influx rate was calculated as the amount of trace element accumulated by the mussel and was normalized per gram dry wt per day ( $\mu \mathrm{g} \mathrm{g}^{-1} \mathrm{~d}^{-1}$ )

The effects of ambient salinity on trace element uptake by mussels from the dissolved phase were experimentally determined. Mussels (from a salinity of $27 \%$ ) were acclimated to different salinities $(20,27$, $34 \%$ ) for $10 \mathrm{~d}$ to minimize differences in clearance rates under different salinities (Widdows 1985). To acclimate to $15 \%$, the lowest salinity that did not disturb mussel behavior, mussels were first acclimated to $20 \%$ for $3 \mathrm{~d}$ and then adjusted down to $15 \%$ for $7 \mathrm{~d}$. During these acclimation periods, mussels were fed with the diatom Thalassiosira pseudonana. Experiments followed the dissolved influx protocol described above. To minimize variation between water batches due to varying dissolved organic matter concentrations, one batch of Southampton surface water was used throughout the experiments, diluted with deionized water as appropriate (with $\mathrm{pH}$ checked). Stable trace element additions were $0.5 \mu \mathrm{g} \mathrm{I}^{-1}$ each for $\mathrm{Cd}$ (in $\mathrm{CdCl}_{2}$ ), $\mathrm{Co}$ (in $\mathrm{CoCl}_{2}$ ), and Se (in $\mathrm{Na}_{2} \mathrm{SeO}_{3}$ ), and $2 \mu \mathrm{gl}^{-1}$ for $\mathrm{Zn}$ (in $\mathrm{ZnCl}_{2}$ ). For $\mathrm{Ag}$ and $\mathrm{Am}$, only ${ }^{110 \mathrm{~m}} \mathrm{Ag}$ (in $0.1 \mathrm{~N}$ $\mathrm{HNO}_{3}$ ) and ${ }^{241} \mathrm{Am}$ (in $3 \mathrm{~N} \mathrm{HNO}_{3}$ ) were added to result in dissolved concentrations of $0.256 \mathrm{~g} \mathrm{l}^{-1}$ and $58 \mathrm{ng} \mathrm{l}^{-1}$, respectively.

Additional experiments were conducted to assess the influence of dissolved organic matter (DOM) on the influx rate of dissolved trace elements into mussels. These experiments used Southampton seawater (SA) and water collected from Stony Brook Harbor (SB) The salinity of the Southampton water was adjusted to $27 \%$ (the salinity of SB water) After adding $\mathrm{H}_{2} \mathrm{O}_{2}(0.8 \%$ by volume), batches of seawater were irradiated with high intensity ultraviolet radiation (1200 W, Ace Hanovia Lamp, Ace Glass Co, Vineland, NJ, USA) to photooxidize the DOM (Armstrong et al 1966). DOM concentrations in UV-oxidized seawater and unirradiated seawater were measured with a Shimadzu TOC
5000 analyzer The $\mathrm{pH}$ of seawater did not change after UV oxidation. Prior to experiments, all glassware for these experiments was baked at $450^{\circ} \mathrm{C}$ for $5 \mathrm{~h}$.

Both UV-oxidized and unirradiated seawater were filtered through $0.2 \mu \mathrm{m}$ polycarbonate membranes. Stable trace elements and radiotracers were then added to give a stable concentration of $1.0 \mu \mathrm{g}^{-1}$ for $\mathrm{Cd}, \mathrm{Co}$ and $\mathrm{Se}$, and $2 \mu \mathrm{g} \mathrm{l^{-1 }}$ for $\mathrm{Zn}$. For Ag and Am, only ${ }^{110 \mathrm{~m}} \mathrm{Ag}$ and ${ }^{241} \mathrm{Am}$ were added, resulting in dissolved concentrations of 0.256 and $0.058 \mathrm{\mu g} \mathrm{l}^{-1}$, respectively. The influx rate of mussels was then determined as described above.

Trace element efflux rates. The diatom Thalassiosira pseudonana was radiolabeled with ${ }^{110 \mathrm{~m}} \mathrm{Ag}+{ }^{109} \mathrm{Cd}+{ }^{57} \mathrm{Co}$, or ${ }^{241} \mathrm{Am}+{ }^{75} \mathrm{Se}+{ }^{65} \mathrm{Zn}$, respectively, following protocols described in Wang \& Fisher (1996a). Radioisotope additions were $41 \mathrm{kBq} \mathrm{l}^{-1}$ for all 6 radioisotopes, corresponding to $42.5 \mathrm{nM}$ for ${ }^{110 \mathrm{~m}} \mathrm{Ag}$ (in $0.1 \mathrm{~N} \mathrm{HNO}_{3}$ ), $15.9 \mathrm{nM}$ for ${ }^{241} \mathrm{Am}$ (in $3 \mathrm{NHNO}_{3}$ ), $2.9 \mathrm{nM}$ for ${ }^{109} \mathrm{Cd}$ (in $0.1 \mathrm{~N} \mathrm{HCl}), 2.4 \mathrm{pM}$ for ${ }^{57} \mathrm{Co}$ (in $\left.0.1 \mathrm{~N} \mathrm{HCl}\right), 0.3 \mathrm{nM}$ for ${ }^{75} \mathrm{Se}$ (as $\mathrm{Na}_{2} \mathrm{SeO}_{3}$ in distilled water), and $6.7 \mathrm{nM}$ for ${ }^{65} \mathrm{Zn}$ (in $0.1 \mathrm{~N} \mathrm{HCl}$ ).

Following 4 d growth, diatom cells had undergone $>5.5$ divisions and reached a concentration of $1.8 \times$ $10^{6}$ cells $\mathrm{ml}^{-1}$ (for ${ }^{110 \mathrm{~m}} \mathrm{Ag}+{ }^{109} \mathrm{Cd}+{ }^{57} \mathrm{Co}$ treatment) and $2.1 \times 10^{6}$ cells $\mathrm{ml}^{-1}$ (for ${ }^{241} \mathrm{Am}+{ }^{75} \mathrm{Se}+{ }^{65} \mathrm{Zn}$ treatment), respectively. Cells were presumed to be uniformly radiolabeled and were collected onto polycarbonate membranes, rinsed with filtered seawater, and resuspended into $200 \mathrm{ml}$ filtered unlabeled seawater. They were stored at $4^{\circ} \mathrm{C}$ for subsequent radioactive feeding of mussels

Five individual mussels were placed in $2 \mathrm{I}$ of $0.2 \mu \mathrm{m}$ filtered seawater. Each day, mussels were fed twice with radioactive diatoms. During each radioactive feeding period (lasting 3 to $4.5 \mathrm{~h}$ ), algae were added into a mussel's feeding chamber every $1.5 \mathrm{~h}$ to produce a suspension of $4.5 \times 10^{4}$ cells ml $\mathrm{ml}^{-1}$ The water was aerated gently and replaced each day. After the radioactive feeding, mussels were transferred to 2 I of unlabeled seawater. Mussels were repeatedly fed under these conditions for $7 \mathrm{~d}$. The contribution of accumulated radioisotope in mussels from the dissolved phase during the feeding period (following desorption from radioactive diatoms) was $<4 \%$ of the total body burden for ${ }^{110 \mathrm{~m}} \mathrm{Ag},{ }^{241} \mathrm{Am},{ }^{75} \mathrm{Se}$ and ${ }^{65} \mathrm{Zn}$, about $11 \%$ of the body burden for ${ }^{109} \mathrm{Cd}$, and $22 \%$ for ${ }^{57} \mathrm{Co}$.

After $7 \mathrm{~d}$ of radioactive feeding, mussels were rinsed with filtered seawater and their radioactivity was counted. They were then transferred individually into $240 \mathrm{ml}$ polypropylene chambers within an enclosed recirculating aerated seawater system, as described above, and were allowed to depurate their incorporated radioisotopes for $20 \mathrm{~d}$. The aquarium water was replaced every week to minimize accumulation of dis- 
solved isotopes and mussel metabolites in the water. Radioactivities in the dissolved phase in this recirculating water were typically not detectable above background levels throughout the $20 \mathrm{~d}$ depuration period. The radioactivity of each mussel was periodically counted; note that gamma analysis is non-destructive, so the same individual mussels could be counted throughout the course of an experiment. Fecal pellets were collected every 2 to $8 \mathrm{~h}$ to minimize desorption of radiotracers from egested feces into the water. At the end of depuration, mussels were dissected and radioactivities associated with shell, gill, food, adductor muscle, digestive gland and remaining soft tissues were determined.

Additional experiments were conducted to assess the efflux rates following uptake of trace elements from the dissolved phase. Two groups of mussels (10 individuals each) were each placed in 21 of $0.2 \mu \mathrm{m}$ filtered seawater and exposed to dissolved ${ }^{110 \mathrm{~m}} \mathrm{Ag}+{ }^{109} \mathrm{Cd}+{ }^{57} \mathrm{Co}$ and ${ }^{241} \mathrm{Am}+{ }^{75} \mathrm{Se}+{ }^{65} \mathrm{Zn}$. Any feces egested by the mussels was collected with a trap held on the bottom of the beaker. Radioisotope additions were $3.7 \mathrm{kBq} \mathrm{l}^{-1}$ for all 6 radiotracers, corresponding to $3.19 \mathrm{nM}$ for ${ }^{110 \mathrm{~m}} \mathrm{Ag}, 1.19 \mathrm{nM}$ for ${ }^{24} \mathrm{Am}, 0.22 \mathrm{nM}$ for ${ }^{109} \mathrm{Cd}, 0.18 \mathrm{pM}$ for ${ }^{57} \mathrm{Co}, 0.02 \mathrm{nM}$ for ${ }^{75} \mathrm{Se}$, and $0.51 \mathrm{nM}$ for ${ }^{65} \mathrm{Zn}$. Each day, mussels were exposed to radioactive seawater for $18 \mathrm{~h}$, and then transferred to unlabeled seawater for $6 \mathrm{~h}$, during which they were fed on unlabeled diatoms. The seawater for radioactive exposure was replaced every day. Throughout the $6 \mathrm{~d}$ uptake period, only a small fraction of radioisotope $(<2 \%)$ was associated with the particulate phase $(>1 \mu \mathrm{m})$. After $6 \mathrm{~d}$ exposure, mussels were rinsed with filtered seawater and their radioactivity determined. They were then transferred into the enclosed recirculating system and depurated for $18 \mathrm{~d}$, as described above

A parallel experiment to this 'long-term' exposure experiment was conducted to assess efflux rates of trace elements obtained from the dissolved phase following short-term exposure, following the same protocol except that exposure was for only $12 \mathrm{~h}$. Periodically, 2 replicate mussels were sacrificed and the radioactivities in the shell, digestive gland, gill, and remaining soft tissues were measured.

Analytical measurements. The radioactivity of whole mussels was assayed non-destructively with a. large-well NaI (Tl) gamma detector Radioactivity of dissected mussel tissues, feces and labeled food particles were measured with a Pharmacia-Wallac LKB gamma counter equipped with a well-type NaI (Tl) crystal. Spillover of radioisotopes was corrected and the 2 gamma counters were intercalibrated. All counts were related to standards for each isotope and corrected for radioactive decay. The gamma emissions of
${ }^{110 \mathrm{~m}} \mathrm{Ag}$ were determined at $658 \mathrm{keV}$, of ${ }^{241} \mathrm{Am}$ at $60 \mathrm{keV}$, of ${ }^{109} \mathrm{Cd}$ at $88 \mathrm{keV}$, of ${ }^{57} \mathrm{Co}$ at $122 \mathrm{keV}$, of ${ }^{75} \mathrm{Se}$ at $264 \mathrm{keV}$, and of ${ }^{65} \mathrm{Zn}$ at $1115 \mathrm{keV}$ Counting times in all samples were adjusted so that the propagated counting errors were typically $<5 \%$

The bioaccumulation model. Trace elements are available to mussels through both dissolved and particulate phases. Bioaccumulation via more than 1 pathway can be described with a kinetic model (Thomann 1981, Landrum et al. 1992, Thomann et al. 1995), assuming that uptake from each source is proportional to its influx. This can be described as:

$\mathrm{d} C / \mathrm{d} t=\alpha_{\mathrm{w}} \times \mathrm{FR} \times C_{\mathrm{w}}+\sum_{i=1}^{n}\left(\mathrm{AE} \times \mathrm{IR} \times C_{f}\right)-\left(k_{\mathrm{e}}+g\right) \times C$

where $C$ is the trace element concentration in mussel soft tissues ( $\mu \mathrm{g} \mathrm{g}^{-1}$ ), $t$ is the time of exposure (d), and $\alpha_{w}$ is the trace element absorption efficiency from the dissolved phase, FR is the mussel filtration rate $\left(\mathrm{l} \mathrm{g}^{-1} \mathrm{~d}^{-1}\right)$. $C_{\mathrm{w}}$ is the dissolved trace element concentration ( $\mathrm{Hg} \mathrm{l}^{-1}$ ). $\mathrm{AE}$ is the trace element assimilation efficiency (\%) from ingested particles, IR is the ingestion rate of mussels $\left(\mathrm{mg} \mathrm{g}^{-1} \mathrm{~d}^{-1}\right), C_{1}$ is the trace element concentration in ingested particles $\left(\mu \mathrm{g} \mathrm{m \textrm {m } ^ { - 1 }}\right), j$ is the food compartment, $k_{e}$ is the efflux rate constant $\left(\mathrm{d}^{-1}\right)$, and $g$ is the growth rate constant $\left(\mathrm{d}^{-1}\right)$, assuming a first order growth. Throughout this study, sample weights are expressed on a dry weight basis.

Under steady-state conditions, Eq. (1) becomes:

$$
C_{\mathrm{ss}}=\frac{\alpha_{\mathrm{w}} \times \mathrm{FR} \times C_{w}+\sum_{j=1}^{\mathrm{n}}\left(\mathrm{AE} \times \mathrm{IR} \times C_{\mathrm{f}}\right)}{k_{\mathrm{e}}+g}
$$

where $C_{s s}$ is the trace element concentration in mussel soft tissues $\left(\mu \mathrm{g} \mathrm{g}^{-1}\right)$ at steady state.

Because some of the parameters in Eq. (2) are not available, several modifications can be made:

$$
I_{\mathrm{u}}=\alpha_{\mathrm{w}} \times \mathrm{FR} \times C_{\mathrm{w}}=k_{\mathrm{u}} \times C_{\mathrm{w}}
$$

where $I_{\mathrm{u}}$ is the influx rate from the dissolved phase ( $\mu \mathrm{g}$ $\mathrm{g}^{-1} \mathrm{~d}^{-1}$ ), which can be measured experimentally, and $k_{1}$ is the dissolved uptake rate constant $\left(\mathrm{g}^{-1} \mathrm{~d}^{-1}\right)$, which equals $\alpha_{w} \times$ FR. Our experiments (see 'Results') show that $I_{\mathrm{u}}$ is directly proportional to $C_{\mathrm{w}}$, thus $k_{\mathrm{u}}$ can be computed from these measurements. When $C_{l}$ is not known, it can be estimated from $C_{w}$ by applying a partition coefficient and the dissolved concentration of a trace element:

$$
C_{1}=C_{w} \times K d
$$

where $K d$ is the partition coefficient of a trace element on the ingested particles $\left(1 \mathrm{~kg}^{-1}\right)$.

For most trace elements, the efflux rates following uptake from the dissolved phase and particulate inges- 
tion are roughly comparable in mussels (see 'Results'). However, if efflux rates are dependent on the routes of uptake, Eq. (2) can be rewritten as:

$$
C_{s s}=\frac{k_{u} \times C_{w}}{k_{e w}+g}+\frac{\sum_{j=1}^{n}\left(\mathrm{AE} \times \mathrm{IR} \times C_{\mathrm{w}} \times K d\right)}{k_{\mathrm{ef}}+g}
$$

where $k_{\text {ew }}$ is the efflux rate constant after uptake from the dissolved phase and $k_{\mathrm{ef}}$ is the efflux rate constant after uptake from ingested particles.

Metal concentrations obtained from the dissolved phase and from food uptake can be described by:

$$
C_{\mathrm{w}, \mathrm{ss}}=\left(k_{\mathrm{u}} \times C_{\mathrm{w}}\right) /\left(k_{\mathrm{ew}}+g\right)
$$

where $C_{w, s s}$ is the metal concentration in mussels at steady state obtained from the dissolved phase $\left(\mu \mathrm{g} \mathrm{g}^{-1}\right)$;

$$
C_{\mathrm{f}, \mathrm{ss}}=\frac{\sum_{j=1}^{\mathrm{n}}\left(\mathrm{AE} \times \mathrm{IR} \times C_{\mathrm{w}} \times K d\right)}{k_{\mathrm{ei}}+g}
$$

where $C_{\mathrm{f}, \mathrm{ss}}$ is the metal concentration in mussels at steady state obtained from food $\left(\mu \mathrm{g} \mathrm{g}^{-1}\right)$. Thus, the relative importance of dissolved uptake and particulate ingestion can be calculated as:

$$
\begin{aligned}
R_{\mathrm{w}} & =C_{\mathrm{w}, \mathrm{ss}} / C_{\mathrm{ss}} \\
R_{\mathrm{f}} & =C_{\mathrm{ss}} / C_{\mathrm{ss}}
\end{aligned}
$$

where $R_{\mathrm{w}}$ is the proportion of accumulated trace element in a mussel obtained from the dissolved phase, and $R_{\mathrm{f}}$ is the proportion of accumulated trace element in a mussel obtained from food.

\section{RESULTS}

\section{Trace element assimilation from ingested natural seston assemblages}

The characteristics of the natural seston during the spring phytoplankton bloom in Long Island Sound are shown in Table 1 Seawater was sampled at high tide and low tide to produce 2 contrasting conditions of particle composition. Seston collected at high tide (March 4) consisted primarily of phytoplankton (>70\% of particles), whereas seston collected at low tide (March 11) consisted mostly of inorganic particles $(>70 \%)$. In both water samples, the phytoplankton assemblage was dominated by the diatom Skeletonema costatum, with chl a concentrations ranging from 11.7 to $17.2 \mathrm{\mu g} \mathrm{l}^{-1}$. At the end of the radiolabeling period, $32 \%$ of ${ }^{110 \mathrm{~m}} \mathrm{Ag}, 76 \%$ of ${ }^{241} \mathrm{Am}, 3 \%$ of ${ }^{100} \mathrm{Cd}$.
$40 \%$ of ${ }^{57} \mathrm{Co}, 3 \%$ of ${ }^{75} \mathrm{Se}$, and $11 \%$ of ${ }^{65} \mathrm{Zn}$ were associated with the seston.

Depuration of the 6 radioisotopes in mussels following pulse radioactive feeding is shown in Fig. 1. Typically, ${ }^{110 \mathrm{mi}} \mathrm{Ag},{ }^{241} \mathrm{Am},{ }^{109} \mathrm{Cd},{ }^{75} \mathrm{Se}$ and ${ }^{65} \mathrm{Zn}$ were rapidly egested within the first $24 \mathrm{~h}$, after which very little was lost from the mussels. The depuration of ${ }^{57} \mathrm{Co}$, however, was characterized by an initial rapid egestion within the first $12 \mathrm{~h}$ and then a slower steady egestion. Assimilation efficiencies (AEs) were calculated as the amount of radioactivity retained at $72 \mathrm{~h}$ divided by the amounts of radioactivity ingested (measured after the $0.5 \mathrm{~h}$ pulse radioactive feeding) (Table 2). AEs were highest for Se and $\mathrm{Zn} \mathrm{(28} \mathrm{to}$ $41 \%$, and were $\leq 20 \%$ for the other elements. Among the 6 trace elements, ${ }^{241} \mathrm{Am}$ was the least available element to the mussels, with an $\mathrm{AE}<1 \%$. AEs measured for the 2 seston assemblages were not significantly different for ${ }^{241} \mathrm{Am},{ }^{57} \mathrm{Co},{ }^{75} \mathrm{Se}$ and ${ }^{65} \mathrm{Zn}$, but were different for ${ }^{110 m} \mathrm{Ag}$ and ${ }^{109} \mathrm{Cd}(\mathrm{p}<0.05) .{ }^{110 \mathrm{~m}} \mathrm{Ag}$ was more efficiently assimilated by mussels when more phytoplankton was present in seston, especially during the second phase of digestion. By contrast, ${ }^{109} \mathrm{Cd}$ was more efficiently assimilated when less chl a was present in the seston.

AEs were also related to the fractions of radioisotopes in the cytoplasm of phytoplankton cells; there was an approximate 1.1 relationship between $A E$ and cytosolic distribution for Am, Co and Se (Fig. 2). Generally, the greater assimilation of $\mathrm{Se}$ and $\mathrm{Zn}$ were related to a higher percentage of these elements in the cytoplasm of the seston. Less Cd was assimilated than would be expected from its cytosolic partitioning. 

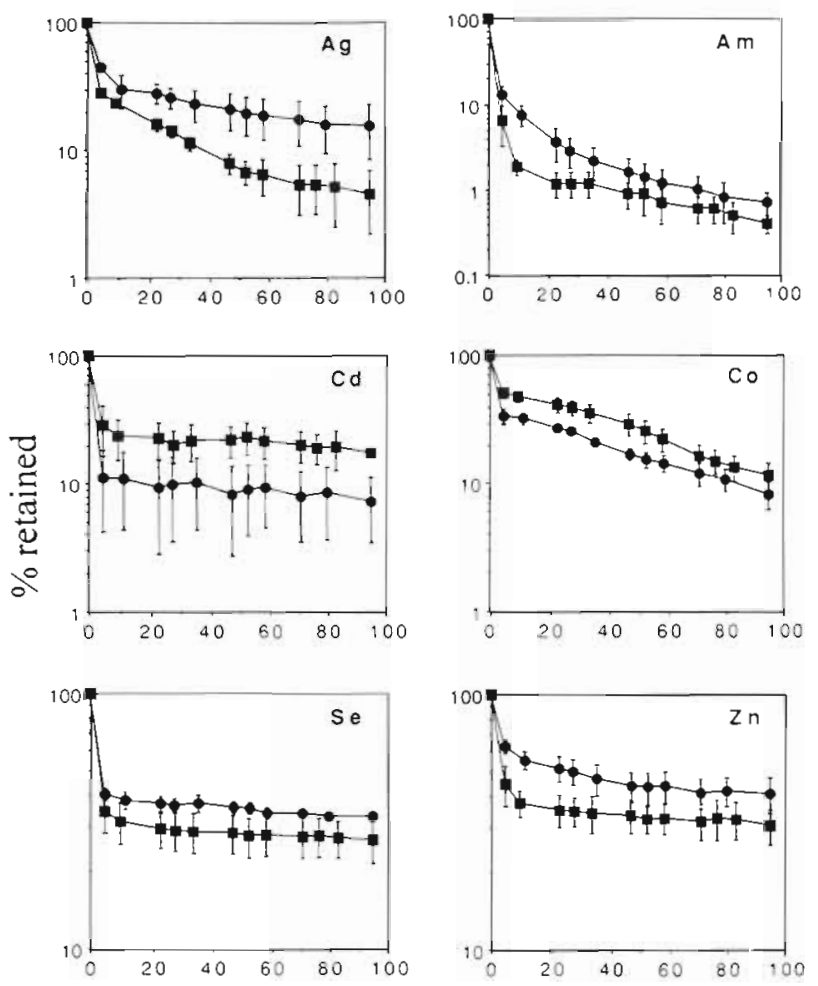

Hours

Fig. 1. Mytilus edulis. Retention of 6 trace elements in whole mussels following ingestion of radiolabeled natural seston. (-) Natural seston with chl a concentration of $17.2 \mu \mathrm{g} \mathrm{l}^{-1}$; (a) natural seston with chl a concentration of $11.7 \mathrm{~kg} \mathrm{l}^{-1}$. Means $\pm \mathrm{SD}(\mathrm{n}=5)$

\section{Uptake of trace elements from the dissolved phase}

A statistically significant $(p<0.001$ ) linear relationship was observed between influx rates of the trace elements from the dissolved phase and the element concentrations in the dissolved phase (Fig. 3, Table 3). The coefficients of this relationship (log-log) for all elements were close to 1 , indicating that uptake proceeded by adsorption and conformed with Freundlich absorption isotherms. Replicate experiments conducted in different years and seasons were directly comparable. The calculated dissolved uptake rate constant (Eq. 3, reflecting differences in efficiency of uptake) was greatest for $\mathrm{Ag}$, followed by $\mathrm{Zn}>\mathrm{Am} \approx$ $\mathrm{Cd}>\mathrm{Co}>\mathrm{Se}$ (Table 3). In these experiments, the filtration rates of mussels were not quantified. To calculate the absorption efficiency of trace elements from the dissolved phase (Table 3 ), the filtration rate of mussels was assumed to be $117 \mathrm{lg}^{-1} \mathrm{~d}^{-1}$ (mean from 26 locations; Widdows et al. 1995). Consequently, the estimated mean absorption efficiencies were $1.53 \%$ for $\mathrm{Ag}, 0.34 \%$ for $\mathrm{Am}, 0.31 \%$ for $\mathrm{Cd}, 0.11 \%$ for $\mathrm{Co}, 0.03 \%$ for Se, and $0.89 \%$ for $\mathrm{Zn}$.
Table 2. Assimilation efficiencies (AEs) of 6 trace elements in mussels ingesting radiolabeled natural seston. Data are means $\pm \mathrm{SD}, \mathrm{n}=5$

\begin{tabular}{|lrr|}
\hline Element & $\begin{array}{c}\text { March 4 } \\
\text { Chl } a, 17.2 \mu \mathrm{g} \mathrm{l}^{-1}\end{array}$ & $\begin{array}{c}\text { March 11 } \\
\text { Chl a, 11.7 } \mu \mathrm{g} \mathrm{I}^{-1}\end{array}$ \\
\hline${ }^{110 \mathrm{~m}} \mathrm{Ag}$ & & \\
${ }^{241} \mathrm{Am}$ & $17.6 \pm 6.8$ & $5.4 \pm 2.3$ \\
${ }^{109} \mathrm{Cd}$ & $1.0 \pm 0.4$ & $0.6 \pm 0.2$ \\
${ }^{57} \mathrm{Co}$ & $8.0 \pm 4.5$ & $20.1 \pm 5.6$ \\
${ }^{75} \mathrm{Se}$ & $11.9 \pm 2.5$ & $16.2 \pm 3.6$ \\
${ }^{65} \mathrm{Zn}$ & $33.9 \pm 1.2$ & $27.5 \pm 4.8$ \\
& $41.1 \pm 5.6$ & $31.9 \pm 5.1$ \\
\hline
\end{tabular}

The influx rate of trace elements from the dissolved phase increased as the salinity decreased from 34 to $20 \%$ (Fig. 4). At 20\%, the influx rate increased by 1.6 to 1.9 times for $\mathrm{Ag}, \mathrm{Cd}, \mathrm{Co}$, Se and $\mathrm{Zn}$ compared to their respective influx rates at $34 \%$, whereas for Am the influx rate was increased by 2.5 times. Between 15 and $20 \%$, however, influx rates for all 6 trace elements remained relatively constant.

The DOM concentrations in Stony Brook (SB) and Southampton (SA) seawater were $2.65 \pm 0.05$ and $1.50 \pm 0.02 \mathrm{mg} \mathrm{l}^{-1}$, respectively. UV photooxidation removed about $50 \%$ of the DOM, with remaining concentrations of $1.30 \pm 0.03$ and $0.74 \pm 0.01 \mathrm{mg} \mathrm{l}^{-1}$ for SB and SA seawater, respectively. Generally, no statistically significant difference in trace element influx rate was detected among different treatments (water batches or DOM levels), although in most cases trace elements in UV-irradiated seawater were accumulated at a slightly greater rate than in unirradiated seawater (Fig. 5). ${ }^{241} \mathrm{Am}$ was accumulated at a rate $>1.5$ times

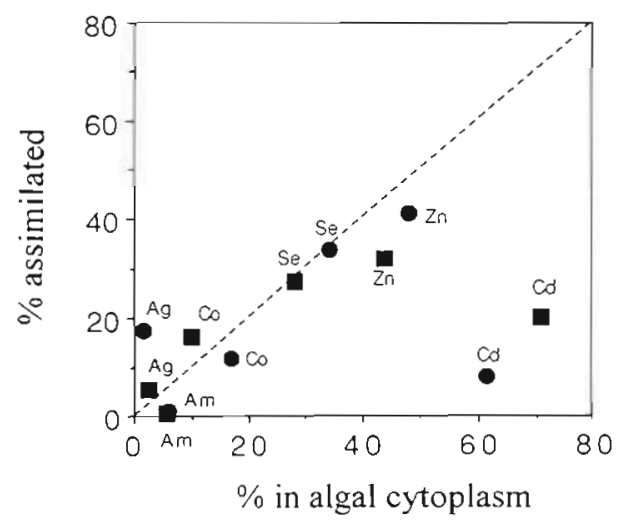

Fig. 2. Mytilus edulis. Relationship of assimilation efficiencies (AE) of trace elements in mussels and their cytoplasmic distributions in natural phytoplankton assemblages used as food. (-) Natural seston with chl a concentration of $17.2 \mathrm{\mu g} \mathrm{l}^{-1}$; natural seston with chl a concentration of $11.7 \mu \mathrm{g} \mathrm{l}^{-1}$ Data points are means of 5 individual mussels. Dotted line indicates a 1:1 relationship 

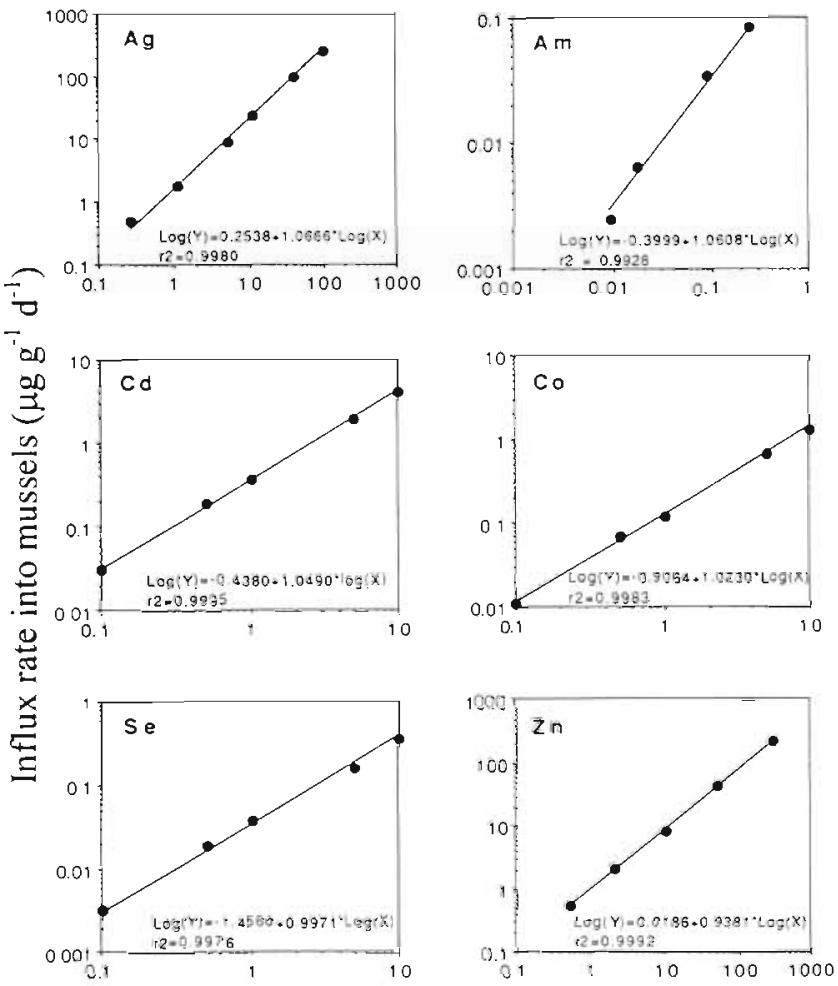

Dissolved concentration $\left(\mu \mathrm{g}^{-1}\right)$

Fig. 3. Mytilus edulis. Influx rates ( $\mu \mathrm{g} \mathrm{g}^{-1} \mathrm{dry}$ wt $\left.\mathrm{d}^{-1}\right)$ of trace elements into mussels from the dissolved phase at different dissolved trace element concentrations. Means $\pm \mathrm{SD}(\mathrm{n}=$ 8). The standard deviations are generally smaller than the symbols

higher in UV-oxidized SB water than in unirradiated SB water.

\section{Efflux rates of trace elements}

Rates of efflux from the most important physiological compartments in the mussels were usually similar whether food or the dissolved phase was the source of

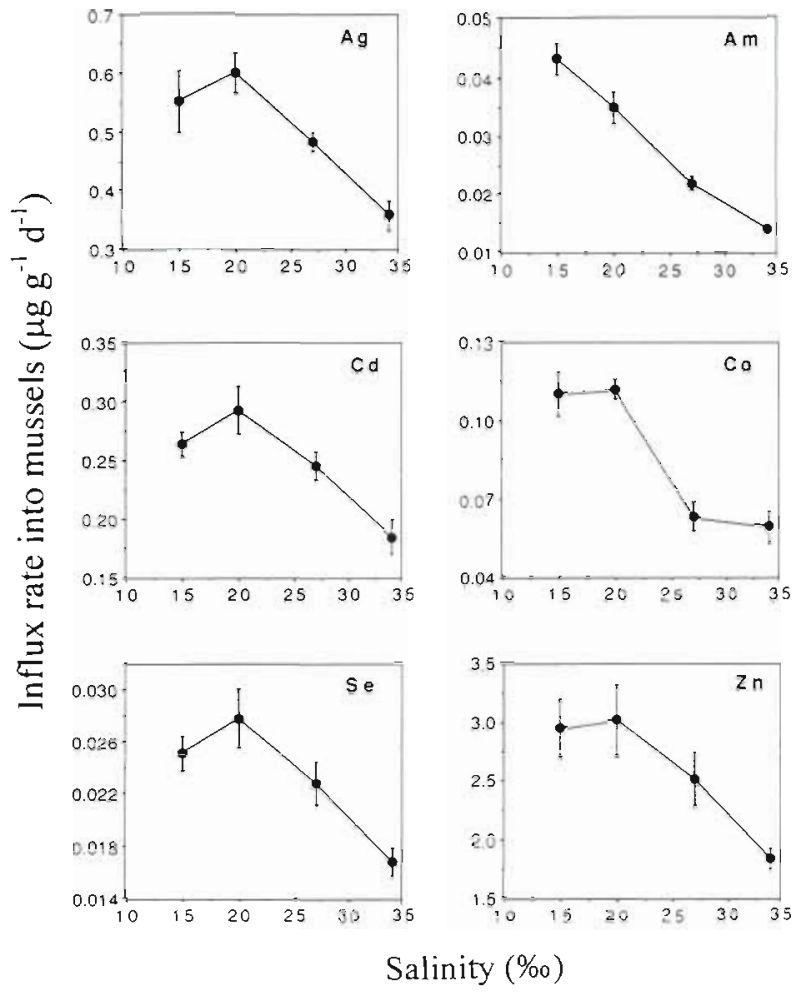

Fig. 4. Mytilus edulis. Influx rates $\left(\mu \mathrm{g} \mathrm{g}^{-1} \mathrm{dry}\right.$ wt $\left.\mathrm{d}^{-1}\right)$ of trace elements into mussels from the dissolved phase at different salinities. Means \pm 1 SE $(n=8)$

exposure. Retention of the 6 radiotracers following $7 \mathrm{~d}$ ingestion of radiolabeled food is shown in Fig. 6. Depuration patterns could be described by 1 -compartmental $\left({ }^{109} \mathrm{Cd}\right), 2$-compartmental $\left({ }^{75} \mathrm{Se}\right)$, or 3-compartmental $\left({ }^{110 \mathrm{~m}} \mathrm{Ag},{ }^{241} \mathrm{Am},{ }^{57} \mathrm{Co}\right.$, and ${ }^{65} \mathrm{Zn}$ ) first-order exponential loss patterns. Physiological rate constants of loss were calculated from the slowest compartment of loss. The rate constants for this compartment ranged from $0.98 \% \mathrm{~d}^{-1}$ for ${ }^{57} \mathrm{Co}$ to $3.4 \% \mathrm{~d}^{-1}$ for ${ }^{110 \mathrm{~m}} \mathrm{Ag}$ [Table 4 also includes the biological half-life $\left(\mathrm{tb}_{1 / 2}\right)$ of each compartment]. The contribution of the slowest compartment ranged from $12 \%$ in $\mathrm{Ag}$ to $95 \%$ in $\mathrm{Cd}$. The most rapid

Table 3. Relationships describing trace element influx rate $\left(I_{u}, \mu \mathrm{g} \mathrm{g}^{-1} \mathrm{~d}^{-1}\right)$ in mussels and dissolved trace element concentration $\left(C_{\mathrm{w}}, \mu \mathrm{g} \mathrm{\textrm {l } ^ { - 1 }}\right)$ in seawater. The ranges of dissolved uptake rate constants $\left(k_{\mathrm{u}}\right)$, calculated using regression of log-transformed influx rates and dissolved concentrations, are also shown. Absorption efficiencies were calculated by dividing $k_{u}$ by the mussel filtration rate (mean $117 \mathrm{I} \mathrm{g}^{-1} \mathrm{~d}^{-1}$; range 52 to $196 \mathrm{l} \mathrm{g}^{-1} \mathrm{~d}^{-1}$ ), from Widdows et al. (1995). Sample weights are on dry wt basis

\begin{tabular}{|c|c|c|c|c|c|}
\hline \multirow[t]{2}{*}{ Element } & \multirow[t]{2}{*}{ Equation } & \multirow[t]{2}{*}{$r^{2}$} & \multirow{2}{*}{$k_{\mathrm{u}}$ range $\left(\mathrm{l} \mathrm{g}^{-1} \mathrm{~d}^{-1}\right)$} & \multicolumn{2}{|c|}{ Absorption efficiency $(\%)$} \\
\hline & & & & Mean & Range \\
\hline $\mathrm{Ag}$ & $I_{\mathrm{u}}=1.794\left[C_{\mathrm{w}}\right]^{1066 \pm 0.024|\mathrm{SE}\rangle}$ & 0.998 & $1.595-2.018$ & 1.53 & $0.92-3.45$ \\
\hline A.m & $I_{\mathrm{u}}=0.398\left[\mathrm{C}_{\mathrm{w}}\right]^{1.061 \pm 0.064(\mathrm{SE})}$ & 0.992 & $0.337-0.470$ & 0.34 & $0.20-0.76$ \\
\hline $\mathrm{Cd}$ & $I_{\mathrm{u}}=0.365\left[C_{\mathrm{w}}\right]^{1.049 \neq 0.014 \text { (SE) }}$ & 0.999 & $0.346-0.384$ & 0.31 & $0.19-0.70$ \\
\hline $\mathrm{Co}$ & $I_{U}=0.124\left[C_{W}\right]^{1.023}=0.024(S E)$ & 0.998 & $0.113-0.136$ & 0.11 & $0.06-0.23$ \\
\hline $\mathrm{Se}$ & $I_{\mathrm{u}}=0.035\left[\mathrm{C}_{\mathrm{w}}\right]^{0.997 \pm 0.028 \mathrm{SE})}$ & 0.998 & $0.032-0.039$ & 0.03 & $0.02-0.07$ \\
\hline $\mathrm{Zn}$ & $I_{u}=1.044\left[C_{w}\right]^{0.938}=0.016$ (SE) & 0.999 & $0.963-1.131$ & 0.89 & $0.53-2.01$ \\
\hline
\end{tabular}



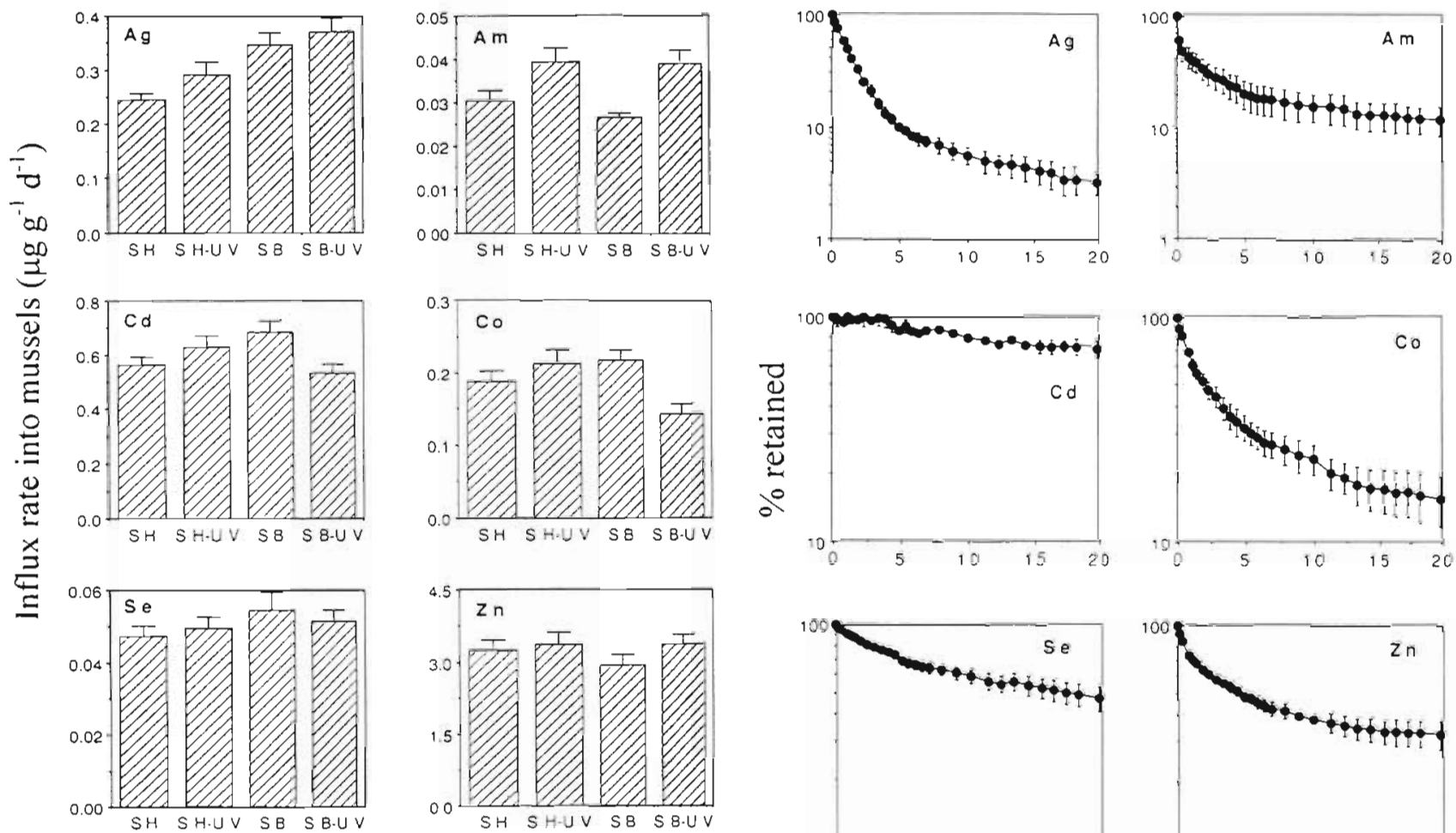

Fig. 5. Mytilus edulis. The influx rates ( $\mu \mathrm{g} \mathrm{g}^{-1}$ dry wt $\mathrm{d}^{-1}$ ) of trace elements into mussels from the dissolved phase using different batches of seawater with and without UV photooxidation. Means $\pm 1 \mathrm{SE}(\mathrm{n}=8)$. SH: Southampton seawater, not UV-oxidized; SH-UV: Southampton seawater, UV-oxidized; SB: Stony Brook Harbor seawater, not UV-oxidized; SB-UV: Stony Brook Harbor seawater, UV-oxidized
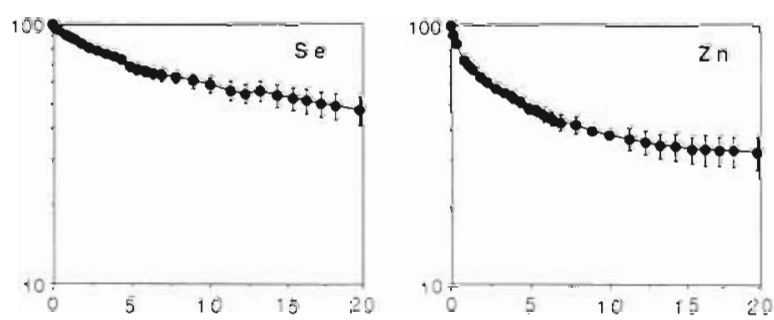

Days

Fig. 6. Mytilus edulis. The retention of 6 trace elements in whole mussels (soft parts and shell) following $7 \mathrm{~d}$ ingestion of the radiolabeled diatom Thalassiosira pseudonana. Means \pm $\mathrm{SD}(\mathrm{n}=5)$

Table 4. Mytilus edulis. Compartmental analysis of trace element depuration in whole mussels following $7 \mathrm{~d}$ ingestion of radiolabeled diatom cells Thalassiosira pseudonana. Each compartment assumed a first order depuration, conforming to $A=A_{0} \times$ $\exp (-k \times t)$, where $A$ is the \% retained at time $t, A_{0}$ is the initial \% retained, and $k$ is the rate constant. The biological half-life $\left(\mathrm{tb}_{1 / 2}, \mathrm{~d}\right)$ of each compartment is also calculated. The depuration rate constant measured in the slowest compartment is representative of the physiological efflux of the trace element. Data are means $\pm S D, n=5$

\begin{tabular}{|lccccc|}
\hline Element & Period $(\mathrm{d})$ & \% in compartment & $k\left(\%, \mathrm{~d}^{-1}\right)$ & $\mathrm{tb}_{1 / 2}(\mathrm{~d})$ & $\mathrm{r}^{2}$ \\
\hline $\mathrm{Ag}$ & $0-4.8$ & $81.2 \pm 2.8$ & $34.1 \pm 3.5$ & $2.1 \pm 0.2$ & 0.970 \\
& $4.8-7.8$ & $7.0 \pm 3.9$ & $5.1 \pm 3.2$ & $22.7 \pm 17.8$ & 0.900 \\
$\mathrm{Am}$ & $7.8-20$ & $11.8 \pm 1.1$ & $3.4 \pm 0.8$ & $22.0 \pm 5.6$ & 0.876 \\
& $0-0.4$ & $47.9 \pm 9.2$ & $154.0 \pm 4.7$ & $0.5 \pm 0.1$ & 0.905 \\
$\mathrm{Cd}$ & $0.4-4.8$ & $23.0 \pm 7.9$ & $11.4 \pm 3.4$ & $7.0 \pm 3.0$ & 0.960 \\
$\mathrm{Co}$ & $4.8-20$ & $29.1 \pm 6.9$ & $2.0 \pm 0.3$ & $35.4 \pm 5.5$ & 0.947 \\
& $5-20$ & $95.4 \pm 6.3$ & $1.4 \pm 0.7$ & $67.4 \pm 39.5$ & 0.714 \\
$\mathrm{Se}$ & $0-3.8$ & $49.7 \pm 5.9$ & $15.5 \pm 2.5$ & $4.6 \pm 0.8$ & 0.939 \\
$\mathrm{Zn}$ & $3.8-12.3$ & $17.2 \pm 5.7$ & $3.2 \pm 0.8$ & $23.6 \pm 7.2$ & 0.929 \\
& $12.3-20$ & $33.0 \pm 0.6$ & $0.98 \pm 0.16$ & $72.3 \pm 10.6$ & 0.868 \\
& $0-6.3$ & $24.6 \pm 5.8$ & $4.2 \pm 1.1$ & $18.5 \pm 6.8$ & 0.983 \\
& $6.3-20$ & $75.4 \pm 5.8$ & $2.2 \pm 0.8$ & $39.1 \pm 21.4$ & 0.921 \\
& $0-1.4$ & $29.5 \pm 3.6$ & $20.9 \pm 2.1$ & $3.3 \pm 0.4$ & 0.967 \\
\end{tabular}


phase of efflux resulted from defecation of ingested radiolabeled material that was not assimilated. Thus, this compartment was largest for those elements least efficiently assimilated (>73\% for ${ }^{110 m} \mathrm{Ag},{ }^{241} \mathrm{Am}$ and ${ }^{57} \mathrm{Co}$ ) and was very small for ${ }^{109} \mathrm{Cd}$ (Table 4 ). This loss was not indicative of physiological efflux.

Depuration patterns following $12 \mathrm{~h}$ or $6 \mathrm{~d}$ uptake from the dissolved phase were typically characterized by at least a 2-compartmental loss pattern (Fig. 7, Table 5). Efflux rate constants calculated from the slowest compartment after $6 \mathrm{~d}$ uptake from the dissolved phase ranged from $1.1 \% \mathrm{~d}^{-1}$ for ${ }^{109} \mathrm{Cd}$ to $2.6 \% \mathrm{~d}^{-1}$ for ${ }^{75} \mathrm{Sc}$ (Table 5). With the exception of ${ }^{110 m} \mathrm{Ag}$, these rates were not significantly different from efflux rate constants measured after $7 \mathrm{~d}$ of food ingestion $(\mathrm{p}>0.05)$. In addition, there were no significant differences in efflux rate constants observed between the $12 \mathrm{~h}$ and $6 \mathrm{~d}$ exposures ( $p>0.05)$, suggesting that the $12 \mathrm{~h}$ exposure was sufficient for the radioisotopes to be partitioned into the slowest compartment. However, the proportion of total radioisotope body burden in the slowest compartment was smaller with the shorter dissolved exposure (Fig. 7 ,
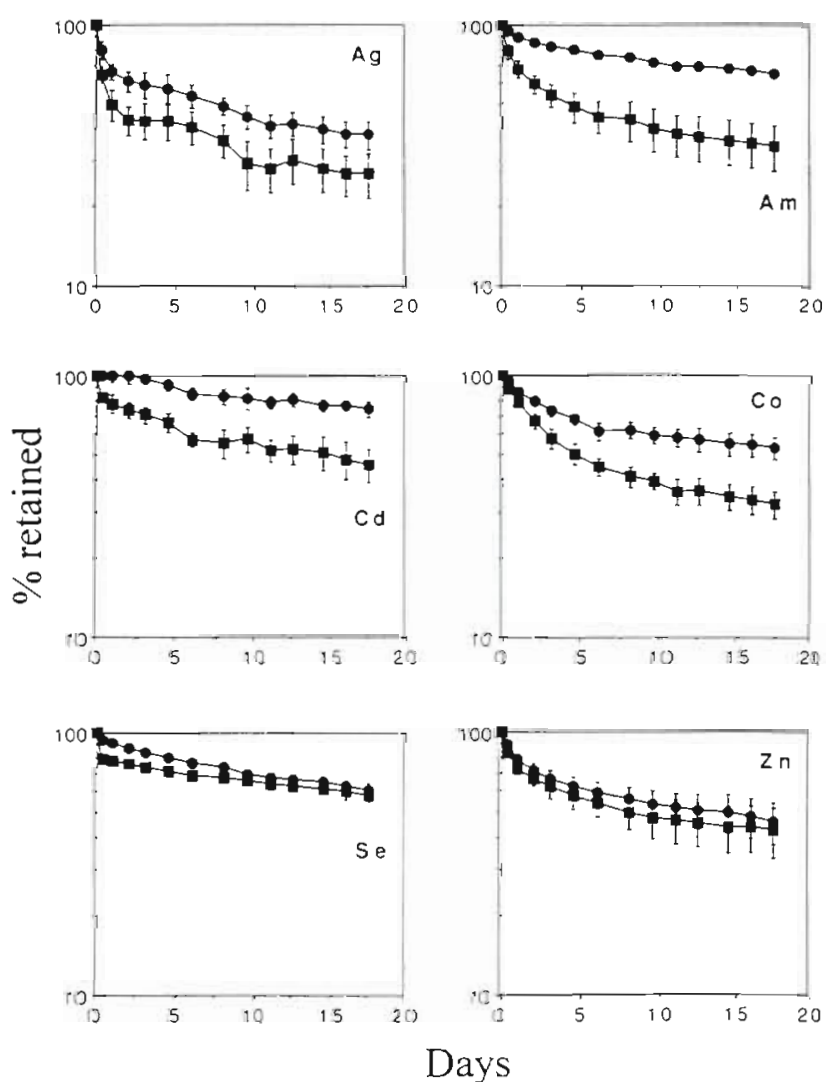

Fig. 7 Mytilus edulis. Retention of 6 trace elements in whole mussels (soft parts and shell) following $12 \mathrm{~h}$ or $6 \mathrm{~d}$ of exposure to the elements in the dissolved phase. ( $12 \mathrm{~h}$ exposure; (•) 6 d exposure. Means $\pm \mathrm{SD}(\mathrm{n}=6$ to 8$)$
Table 5). The greatest loss rates occurred within the first $24 \mathrm{~h}$ of depuration, presumably due to rapid desorption and possibly defecation.

After $7 \mathrm{~d}$ of radioactive feeding, substantial fractions (10 to $30 \%$ ) of ${ }^{110 \mathrm{~m}} \mathrm{Ag},{ }^{241} \mathrm{Am}$, and ${ }^{57} \mathrm{Co}$ were found on the shells, whereas most of ${ }^{109} \mathrm{Cd},{ }^{75} \mathrm{Se}$, and ${ }^{65} \mathrm{Zn}$ was associated with the digestive glands and soft tissues (Fig. 8). In the experiments assessing radioisotope uptake from the dissolved phase, it is apparent from the tissue distributions of the radioisotopes that, with the exception of ${ }^{109} \mathrm{Cd}$, the shells contained much of the accumulated radioisotopes (Fig. 9).

\section{Kinetic modeling of trace element accumulation in mussels}

The kinetic model described in Eq. (2) requires measurements of trace element AE in the mussel, influx rate constant from the dissolved phase $\left(k_{\mathrm{u}}\right)$, efflux rates $\left(k_{\mathrm{e}}\right)$, mussel ingestion rate (IR), the dissolved concentration $\left(C_{w}\right)$, and partition coefficients $(K d)$ for sus-
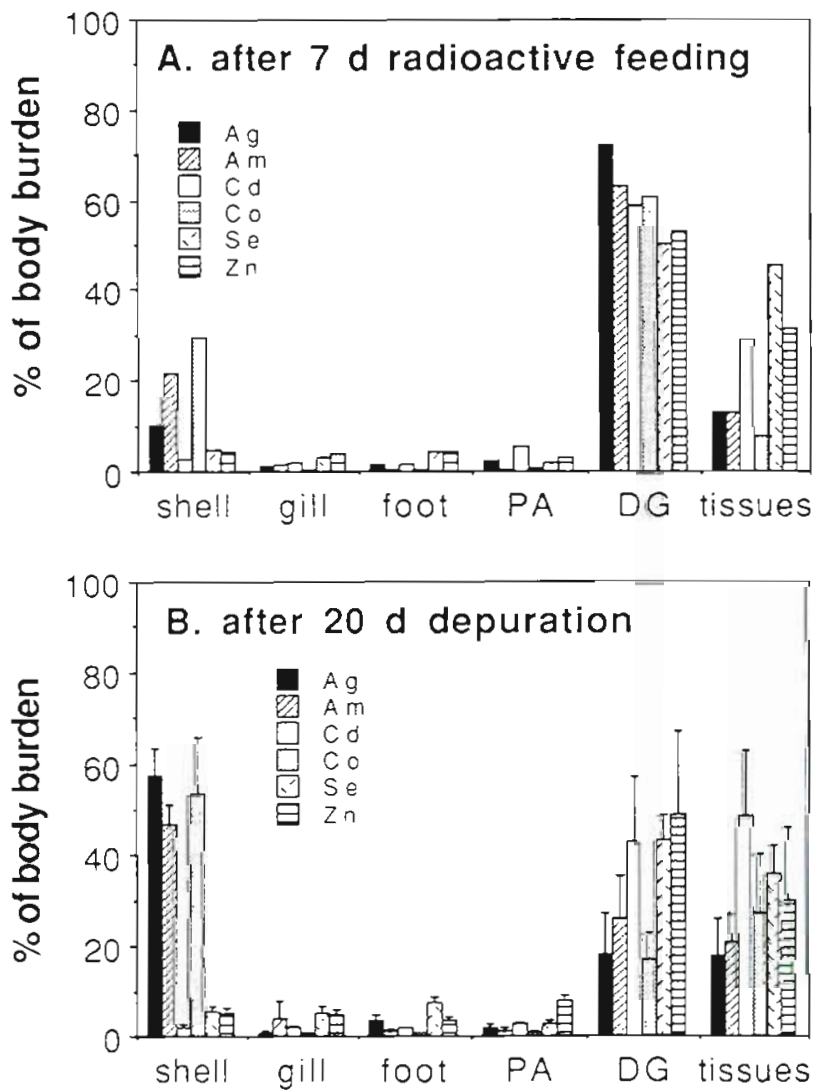

Fig. 8. Mytilus edulis. Distribution of 6 radiotracers in mussel tissues (A) after $7 \mathrm{~d}$ ingestion of the radiolabeled diatom Thalassiosira pseudonana and (B) after $20 \mathrm{~d}$ of depuration. Means $\pm S D(n=2)$. PA: postenor adductor; $D G$ : digestive gland 
Table 5. Mytilus edulis. Compartmental analysis of trace element depuration in whole mussels following $12 \mathrm{~h}$ and $6 \mathrm{~d}$ dissolved uptake, respectively. Each compartment assumed a first order depuration, conforming to $A=A_{0} \times \exp (-k \times t)$, where $A$ is the \% retained at time $t, A_{0}$ is the initial \% retained, and $k$ is the rate constant. The depuration rate constant measured in the slowest compartment is representative of the physiological efflux of trace element. The biological half-life ( $\mathrm{tb}_{1 / 2}$ ) of each compartment is also shown. Data are means $\pm \mathrm{SD}, \mathrm{n}=6$ to 8

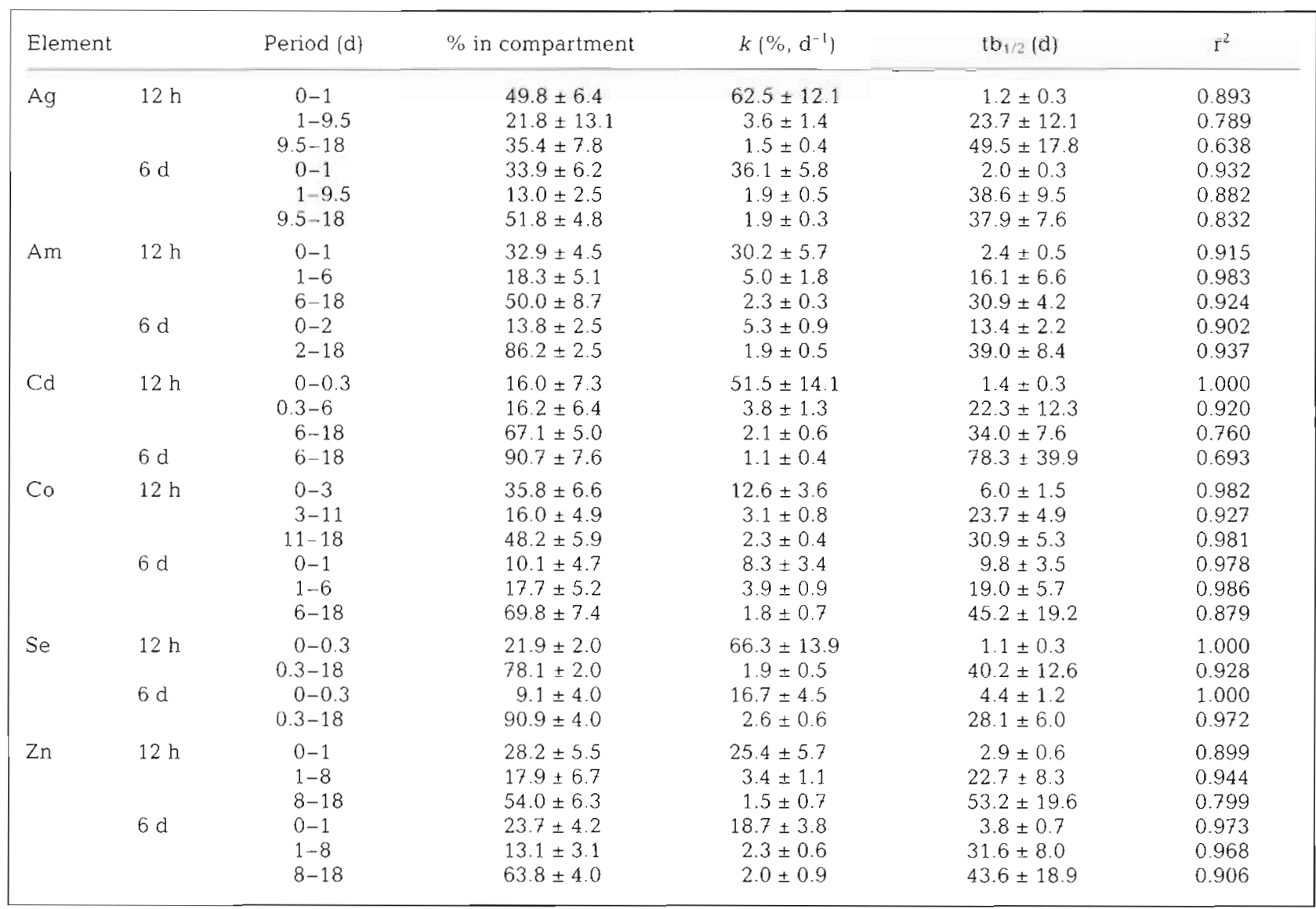

pended particles (if direct trace element concentrations on these particles are not known). Model predictions for a specific environment require reliable data for trace element concentrations in seawater and in seston; field verification can be accomplished by concurrent analyses of mussel tissues.

Bayne et al. (1987, 1993) measured mussel ingestion rates on seston prepared from mixtures of silt and algae with a wide range of organic content ( 9 to $72 \%$ ). These studies showed that mussels regulated their feeding activity in response to short-term changes in their diets and were able to maintain ingestion rates in a simple relationship with the seston concentration (Bayne 1993). Calculations using Bayne et al.'s (1987. 1993) data gave the following relationship between ingestion rate of seston, IR $\left(\mathrm{mg} \mathrm{g}^{-1} \mathrm{~d}^{-1}\right)$ and total seston concentration (TSS, $\mathrm{mg} \mathrm{l}^{-1}$ ):

$$
\mathrm{IR}=137[\mathrm{TSS}]^{0.4212}\left(\mathrm{r}^{2}=0.573\right)
$$

Mussels produce pseudofeces at high seston concentrations ( $\geq 5 \mathrm{mg} \mathrm{l}^{-1}$; Widdows et al. 1979) and maintain a maximum ingestion rate beyond this level. Thus, at seston concentrations $\geq 5 \mathrm{mg} \mathrm{l}^{-1}$, the mussels were assumed to maintain a maximum ingestion rate of $270 \mathrm{mg} \mathrm{g}^{-1} \mathrm{~d}^{-1}$. The growth rate constant $10.0019 \mathrm{~d}^{-1}$; Thomann 1981, Connolly 1991) is 1 order of magnitude lower than the efflux rate constant measured in this study. Therefore, the growth rate constant was ignored in our modeling calculations.

Table 6 summarizes the biological parameters for each trace element employed in the bioaccumulation modeling. AEs were taken from previous studies (Wang \& Fisher 1996a, b) and this study in order to take into account a diversity of feeding strategies. AEs of trace elements in mussels decrease slightly with increasing amounts of food material they ingest (Wang et al. 1995). Since suspended particle loads are relatively high in mussel beds and shallow coastal waters, a lower range of AEs observed for diverse phytoplankton cells (Wang \& Fisher 1996a) and natural seston (Table 2) was employed in our modeling. 

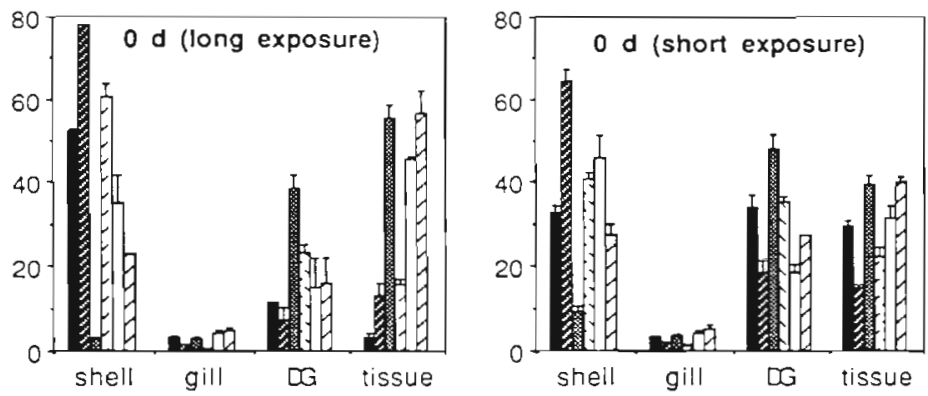

Smith \& Flegal 1993, Wood et al. 1995). Below, we use the low and high dissolved concentrations measured at Dumbarton Bridge Station to model trace element concentrations in mussels and compare these with NS\&T measurements of trace elements in mussels at this station (South SFB). Seston concentrations at this station were typically $>10 \mathrm{mg} \mathrm{I}^{-1}$, therefore a maximum mussel ingestion rate $\left(270 \mathrm{mg} \mathrm{g}^{-1}\right.$
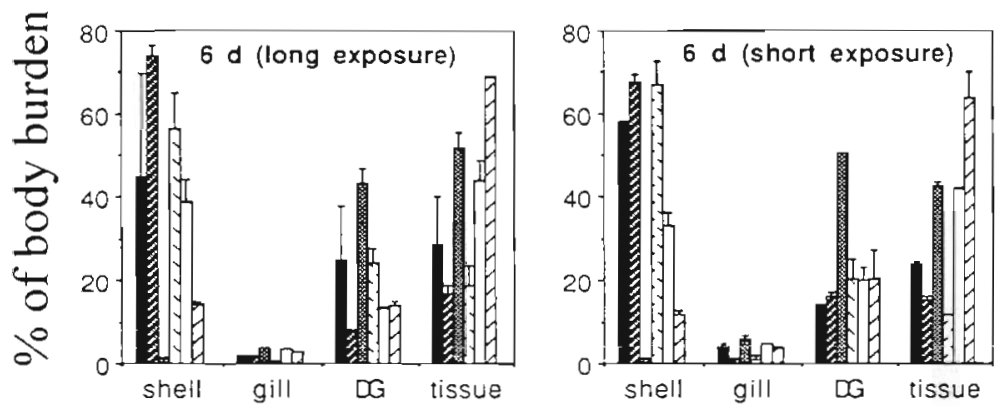
$\mathrm{d}^{-1}$, calculated from Eq. 10) was assumed. The partition coefficients for Ag, Cd, Se and $\mathrm{Zn}$ in SFB are shown in Table 7 . Partition coefficients for each element are dependent on environmental conditions, particularly the composition of the seston and possibly salinity. The $K d$ for $\mathrm{Cd}$ given in Kuwabara et al. (1989) was multiplied by a factor of 2 , because their measurements of dissolved Cd concentrations were underestimated by a factor of 2 (Wood et al. 1995). An average $K d$ for each trace element measured in SFB was employed. Selenium speciates in seawater as selenite, selenate, elemental selenium, and organic selenides (Cutter \& Bruland 1984), but we only modeled selenite bioaccumulation from our experiments which used dissolved selenite uptake. The selenite concentration factor in phytoplankton based on studies with selenite (geometric mean of $2.8 \times 10^{4}$; Fisher \& Reinfelder 1995) is generally higher than values calculated with field measurements, which are based on living and abiotic suspended particles and total dissolved selenium concentra-

The concentrations and partitioning of trace elements in San Francisco Bay (SFB) have been extensively studied using trace element clean techniques (Cutter 1989, Kuwabara et al. 1989, Flegal et al. 1991.

Table 6. Trace element parameters used in the bioaccumulation modeling. $k_{\mathrm{u}}$ : uptake rate constant from the dissolved phase; AE: assimulation efficiency; $k_{\text {ef }}$ efflux rate constant after food uptake $k_{\text {ew }}$ : efflux rate constant after dissolved uptake. AE values from Wang \& Fisher (1996a)

\begin{tabular}{|lcccc|}
\hline Element & $\begin{array}{c}k_{\mathrm{u}} \\
\left(\mathrm{g} \mathrm{g}^{-1} \mathrm{~d}^{-1}\right)\end{array}$ & $\begin{array}{c}\mathrm{AE} \\
(\%)\end{array}$ & $\begin{array}{c}k_{\mathrm{e}} \\
\left(\mathrm{d}^{-1}\right)\end{array}$ & $\begin{array}{c}k_{\text {ew }} \\
\left(\mathrm{d}^{-1}\right)\end{array}$ \\
\hline $\mathrm{Ag}$ & 1.794 & $4-34$ & 0.034 & 0.019 \\
$\mathrm{Am}$ & 0.398 & $1-6$ & 0.020 & 0.019 \\
$\mathrm{Cd}$ & 0.365 & $11-40$ & 0.014 & 0.011 \\
$\mathrm{Co}$ & 0.124 & $20-43$ & 0.0098 & 0.018 \\
$\mathrm{Se}$ & 0.035 & $15-72$ & 0.022 & 0.026 \\
$\mathrm{Zn}$ & 1.044 & $16-48$ & 0.015 & 0.020 \\
\hline
\end{tabular}

tion. We therefore chose a $K d$ value of $1 \times 10^{4}$ for selenite in our modeling

For comparative purposes we also modeled bioaccumulation in mussels in Long Island Sound (LIS). We calculated the likely dissolved concentrations in LIS based on the measurements of Hunt (1979) of trace metal concentrations in net phytoplanktor collected from LIS in 1976, using geometric mean phytoplankton concentration factors (Fisher \& Reinfelder 1995). Trace metal concentrations predicted in mussel tissues in LIS were compared with LIS data for mussel soft parts (Goldberg et al. 1983) measured at the same time as Hunt's (1979) study.

Under different environmental conditions likely to be encountered by the mussels in SFB and LIS, the trace element concentrations predicted from the independent laboratory experiments for mussel tissues using Eq. (5) were strikingly close to the actual tissue concentrations measured in the monitoring programs 
Table 7 Partition coefficient ( $K d, 1 \mathrm{~kg}$ dry $\mathrm{wt}^{-1}$ ) of trace elements in seston measured in South San Francisco Bay (California, USA). Am and Co Kds in coastal sediments and phytoplankton are taken from IAEA (1985) and Fisher \& Reinfelder (1995) (dry wt basis using a mean vol:dry wt ratio of 4.75 ; Fisher et al. 1983a)

\begin{tabular}{|c|c|c|c|}
\hline Element & $K d$ & Mean $K d$ & Source \\
\hline $\mathrm{Ag}$ & $6.3 \times 10^{4}-4.0 \times 10^{5}$ & $1.6 \times 10^{5}$ & Smith \& Flegal (1993) \\
\hline $\mathrm{Cd}$ & $4 \times 10^{3}-6 \times 10^{3}$ & $5 \times 10^{3}$ & Kuwabara et al. (1989) \\
\hline $\mathrm{Se}$ & $2 \times 10^{3}-6 \times 10^{3}$ & $4 \times 10^{3}$ & Cutter (1989) \\
\hline $\mathrm{Zn}$ & $1.6 \times 10^{4}-2.2 \times 10^{4}$ & $1.9 \times 10^{4}$ & Kuwabara et al. (1989) \\
\hline \multirow[t]{2}{*}{ Am } & $10^{5}-2 \times 10^{7}$ (coastal sediments) & $2 \times 10^{6}$ & $\operatorname{IAEA}(1985)$ \\
\hline & Phytoplankton & $7.6 \times 10^{5}$ & Fisher \& Reinfelder (1995) \\
\hline \multirow[t]{2}{*}{ Co } & $2 \times 10^{4}-10^{\overline{5}}$ (coastal sediments) & $2 \times 10^{5}$ & IAEA $\{1985\}$ \\
\hline & Phytoplankton & $2.1 \times 10^{3}$ & Fisher \& Reinfelder (1995) \\
\hline
\end{tabular}

(Table 8). For Cd and Se in both SFB and LIS, and Zn in LIS, the predicted concentrations were within the ranges of actual measured concentrations in mussels. For $\mathrm{Ag}$ in both SFB and LIS and $\mathrm{Zn}$ in SFB, the highest predicted metal concentrations in mussel tissues using the highest dissolved concentrations and the high AEs were 2 to $3 \times$ higher than the metal concentrations measured in the field.

Table 8. Mytilus edulis. Model-predicted trace element concentration in mussel tissues $\left(C_{\mathrm{ss}}\right)$ and its comparison with field-measured concentration $\left(C_{\text {measured }}\right.$ ) in mussels collected from Dumbarton Bridge, South San Francisco Bay (data from NS\&T Program, T. P. O'Connor pers. comm.) and Long Island Sound (data from Goldberg et al. 1983). Seston concentrations at these stations were $>7 \mathrm{mg} \mathrm{l}^{-1}$, thus a maximum ingestion rate of $270 \mathrm{mg} \mathrm{g}^{-1} \mathrm{~d}^{-1}$ was assumed for mussels (calculated from Eq. 10). Both the lowest and highest dissolved concentrations were included in modeling $(\mathrm{Ag}, \mathrm{Cd}$ and $\mathrm{Zn}$ dissolved concentration in SFB were from Flegal et al. 1991; Se data was from Cutter 1989). Also shown are the proportion of total body burden of each metal predicted to come from the dissolved phase. See text for detailed discussion of parameters. Sample weights are on dry wt basis

\begin{tabular}{|c|c|c|c|c|c|c|}
\hline Element & $\begin{array}{c}C_{\mathrm{w}} \\
\left(\mu \mathrm{g} \mathrm{I}^{-1}\right)\end{array}$ & $K d$ & $\mathrm{AE}$ & $\begin{array}{c}C_{\mathrm{s} 5} \\
\left.(\mu \mathrm{g} \mathrm{g})^{-1}\right)\end{array}$ & $\begin{array}{l}C_{\text {measured }} \\
\left(\mathrm{Hg} \mathrm{g}^{-1}\right)\end{array}$ & $\%$ dissolved \\
\hline \multicolumn{7}{|c|}{ San Francisco Bay } \\
\hline \multirow[t]{4}{*}{$\mathrm{Ag}$} & 0.0026 & 150000 & 0.04 & 0.29 & \multirow{4}{*}{$0.35-0.77$} & 57 \\
\hline & 0.0097 & 150000 & 0.04 & 1.15 & & 59 \\
\hline & 0.0026 & 150000 & 0.12 & 0.54 & & 31 \\
\hline & 0.0097 & 150000 & 0.12 & 2.09 & & 33 \\
\hline \multirow[t]{4}{*}{$\mathrm{Cd}$} & 0.07 & 5000 & 0.1 & 2.7 & \multirow[t]{4}{*}{$4.4-9.4$} & 76 \\
\hline & 0.17 & 5000 & 0.1 & 6.8 & & 76 \\
\hline & 0.07 & 5000 & 0.3 & 4.1 & & 51 \\
\hline & 0.17 & 5000 & 0.3 & 10.1 & & 52 \\
\hline \multirow{4}{*}{$\begin{array}{l}\text { Se } \\
\text { (selenite) }\end{array}$} & 0.025 & 10000 & 0.3 & 1.0 & \multirow[t]{4}{*}{$2.5-6.7$} & 3.6 \\
\hline & 0.065 & 10000 & 0.3 & 2.5 & & 3.6 \\
\hline & 0.025 & 10000 & 0.7 & 2.2 & & 1.6 \\
\hline & 0.065 & 10000 & 0.7 & 5.6 & & 1.6 \\
\hline \multirow[t]{4}{*}{$\mathrm{Zn}$} & 0.5 & 20000 & 0.15 & 54 & \multirow[t]{4}{*}{$54-130$} & 52 \\
\hline & 1.7 & 20000 & 0.15 & 176 & & 50 \\
\hline & 0.5 & 20000 & 0.3 & 80 & & 35 \\
\hline & 1.7 & 20000 & 0.3 & 265 & & 33 \\
\hline \multicolumn{7}{|c|}{ Long Island Sound } \\
\hline \multirow[t]{4}{*}{$\mathrm{Ag}$} & 0.0038 & 150000 & 0.04 & 0.43 & \multirow[t]{4}{*}{$0.04-0.44$} & 58 \\
\hline & 0.0044 & 150000 & 0.04 & 0.51 & & 58 \\
\hline & 0.0038 & 150000 & 0.12 & 0.80 & & 31 \\
\hline & 0.0044 & 150000 & 0.12 & 0.93 & & 31 \\
\hline \multirow[t]{4}{*}{$\mathrm{Cd}$} & 0.074 & 5000 & 0.1 & 2.9 & \multirow[t]{4}{*}{$1.5-6.2$} & 76 \\
\hline & 0.120 & 5000 & 0.1 & 4.8 & & 76 \\
\hline & 0.074 & 5000 & 0.3 & 4.3 & & 51 \\
\hline & 0.120 & 5000 & 0.3 & 7.0 & & 51. \\
\hline \multirow[t]{4}{*}{$\mathrm{Zn}$} & 0.315 & 20000 & 0.15 & 34 & \multirow[t]{4}{*}{$52-142$} & 52 \\
\hline & 1.000 & 20000 & 0.15 & 105 & & 51 \\
\hline & 0.315 & 20000 & 0.3 & 51 & & 36 \\
\hline & 1.000 & 20000 & 0.3 & 157 & & 34 \\
\hline
\end{tabular}




\section{Determining the relative contributions of dissolved and particulate uptake routes}

The proportion of the overall trace element accumulation in mussel tissues that is attributable to uptake from the dissolved phase was calculated at various dissolved concentrations with changing $\mathrm{AE}, K d$, and seston concentration. Because Kd's were employed to determine $C_{f}(E q .4)$, the relative importance of different uptake pathways is independent of $C_{w}$ (see Eqs. 6 to 9) at steady state. Fig. 10 presents calculations for each trace element at various Kd, AE, and TSS values using assumptions described for the calculation of $C_{s s}$. More than $96 \%$ of Se bioaccumulation is calculated to be from food ingestion under various environmental conditions. For the other trace elements $(\mathrm{Ag}, \mathrm{Am}, \mathrm{Cd}, \mathrm{Co}, \mathrm{Zn}\}$, the contribution of dissolved uptake depends on changes in environmental and physiological factors, decreasing with increasing $\mathrm{Kd}$ and with increasing AE. The total particle load has a relatively minor effect on the proportion of accumulated trace element from the dissolved phase, primarily because of the slightly inverse effect on $\mathrm{AE}$ and a constant ingestion rate at seston loads $>5$ $\mathrm{mg} \mathrm{l}^{-1}$. Under most of these conditions, $>50 \%$ of the $\mathrm{Cd}$ in mussels is from the dissolved phase, whereas $>80 \%$ of $\mathrm{Am},>70 \%$ of $\mathrm{Co}$, and $>50 \%$ of $\mathrm{Zn}$ in mussels are directly from ingested particles. The pathways of Ag bioaccumulation differ most widely, with 30 to $70 \%$ coming from the dissolved phase.
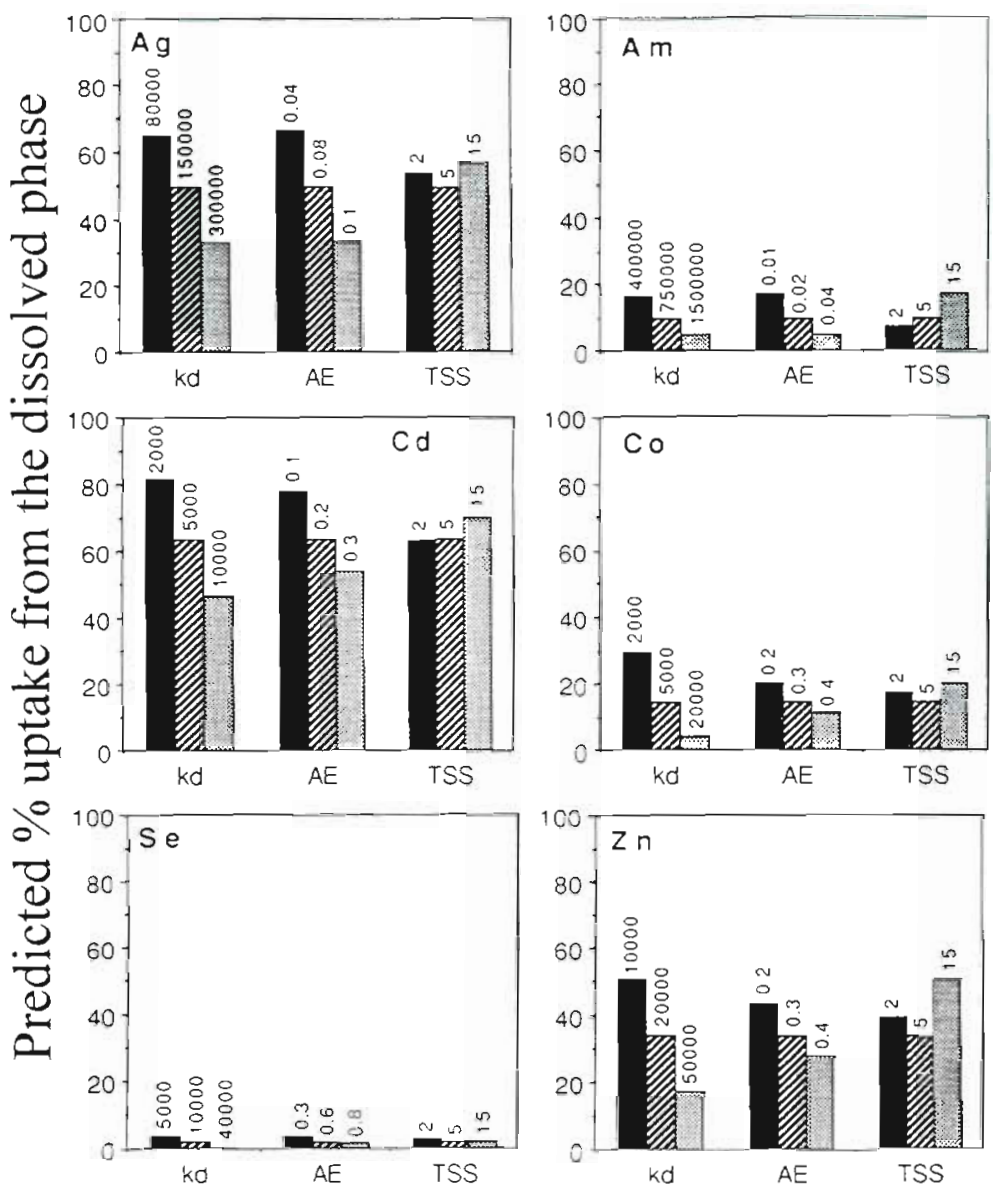

Fig. 10. Mytilus edulis. The calculated proportion $(\%)$ of the total trace element concentration in mussels from the dissolved phase over a range of different partition coefficients $(K d)$, assimilation efficiencies (AE), and seston (TSS) loads ( 2 to $15 \mathrm{mg}$ dry wt $\mathrm{l}^{-1}$ ). The range of $K d$ and AE values used are specific to each element and are based on observed values (see also Tables 6 \& 7). Calculations for each parameter (e.g. Kd) assume intermedlate values of the other 2 parameters (e.g. AE and TSS load) shown in the figure. See text for further explanation

\section{Factors affecting metal bioaccumulation in mussels}

An analysis was also performed to quantify the influence of changes in $C_{t}$, TSS, $K d$, salinity, and AE on trace element concentrations in mussel tissues. Because $C_{w}$ (dissolved concentration, $\mu \mathrm{g}^{-1}$ ) and $C_{1}$ (particulate con-

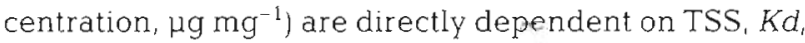
and the total concentration $\left(C_{1} \mu \mathrm{g} \mathrm{l}^{-1}\right)$ of trace element in the water column (that is, dissolved plus particulate trace element concentration), we calculated predicted values of $C_{\mathrm{w}}$ and $C_{\mathrm{f}}$ as a function of $C_{\mathrm{t}}$ at different TSS (total suspended solids) loads, assuming that $K d$ is independent of TSS loads (Fig, 11).

$$
C_{\mathrm{t}}=C_{\mathrm{v}}+\left(C_{\mathrm{t}} \times \mathrm{TSS}\right)
$$

Thus

$$
C_{1}=C_{w}+\left(C_{w} \times K d \times \text { TSS }\right)
$$

$$
C_{w}=[1 /(1+\operatorname{TSS} \times K d)] \times C_{1}
$$

Calculations using Eqs. (4) and (13) are shown in Fig. 11. Note that $C_{t}$ is an independent variable and need not be constant. Both dissolved and particulate concentrations decline with increasing TSS loads, particularly for trace elements with $K d$ values $>10^{4}$

Total metal concentration in the water column

Applying Eq. (13) to Eq. (5) it can be shown that

$C_{\mathrm{ss}}=\left(\frac{k_{\mathrm{u}}}{k_{\mathrm{ew}}+g}+\frac{\mathrm{AE} \times \mathrm{IR} \times K d}{k_{\mathrm{ef}}+g}\right) \times\left(\frac{1}{1+\mathrm{TSS} \times K d}\right) \times C_{\mathrm{t}}$

By applying Eq. (4), Eq. (11) then becomes 

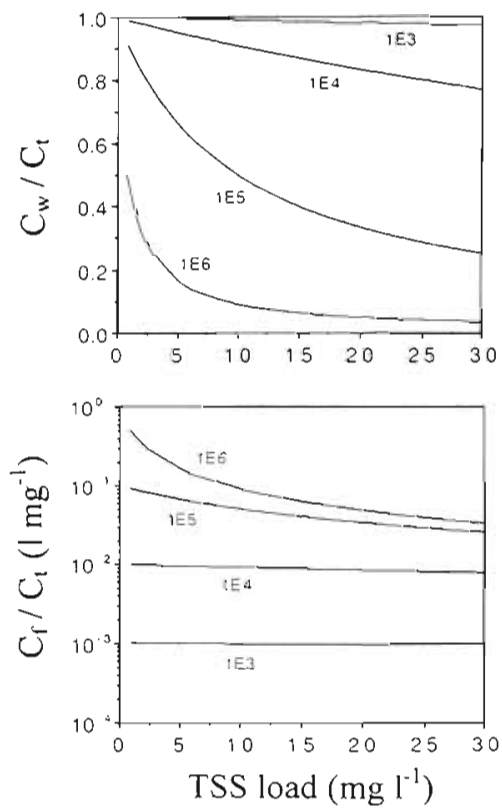

Fig. 11. Predicted cange in the ratios of metal concentrations in the dissolved $\left(C_{w}\right)$ and particulate $\left(C_{1}\right)$ phases to total metal concentration $\left(C_{t}\right)$ at different total suspended solids (TSS) loads ( 1 to $30 \mathrm{mg}$ dry wt $\mathrm{l}^{-1}$ ) and $K d \mathrm{ds}\left(10^{3}\right.$ to $10^{6}$ ). These calculations assume that $K d s$ are independent of the TSS load (Eqs. 4 \& 13)

Eq. (14) conceptually illustrates the variety of factors that can affect bioaccumulation. $C_{\text {ss }}$ is directly proportional to $C_{1}$ under all conditions, consistent with the fundamental concept underlying the Mussel Watch Program. However, the environment and the organism can influence bioavailability, i.e. there is no constant proportionality between $C_{\mathrm{ss}}$ and $C_{\mathrm{t}}$. Changes in any of the parameters described in Eq. (1.4) can greatly affect the ratio of $C_{s s}$ to $C_{t}$ a mathematical expression of the widely employed bioaccumulation factor (BAF). The BAF as defined here thus considers both dissolved and particulate metal uptake in mussels.

$\mathrm{BAF}=\frac{C_{\mathrm{ss}}}{C_{\mathrm{t}}}=\left(\frac{k_{\mathrm{u}}}{k_{\mathrm{ew}}+g}+\frac{\mathrm{AE} \times \mathrm{IR} \times K d}{k_{\mathrm{ef}}+g}\right)\left(\frac{1}{1+\mathrm{TSS} \times K d}\right)$

Total suspended solids loads

TSS loads can affect several parameters in the bioaccumulation model, including $C_{\mathrm{w}}$ (Eq. 13), IR (Eq. 10) and AE. For all our calculations, IR was assumed to be $270 \mathrm{mg} \mathrm{g}^{-1} \mathrm{~d}^{-1}$ at TSS $>5 \mathrm{mg} \mathrm{l}^{-1}$. AE was assumed to vary by a factor $<2$ over a TSS range of 1 to $20 \mathrm{mg} \mathrm{l}^{-1}$, with AEs increasing inversely with TSS loads (Wang et al. 1995). Using Eq. (15), BAF values were calculated for different TSS loads. The greatest effect of TSS load on BAF was found for $\mathrm{Ag}$ and $\mathrm{Am}$, both of which are particle-reactive metals with $K d$ values $>10^{5}$ (Fig. 12). For these metals, with increasing TSS loads, metal concentrations in both dissolved and particulate phases decline appreciably, resulting in a precipitous decline in metal concentration in mussel tissues ( $>3 \times$ for $\mathrm{Ag}$ and $>10 \times$ for Am). TSS loads have a much less pronounced effect on BAF for Cd and Co (Fig. 12), primarily due to their lower $K d$ values (about 5000). At the lower range of TSS loads, BAF increases with TSS load for $\mathrm{Cd}, \mathrm{Co}, \mathrm{Se}$, and $\mathrm{Zn}$ due to a significant increase in IR and a relatively small effect of $K d$ on $C_{w}$. However, with increasing TSS loads ( $>5 \mathrm{mg} \mathrm{l}^{-1}$ ), BAF declines due to a decrease in $A E$ and $C_{w}$.

\section{Assimilation efficiency}

In contrast to the effects of TSS load, BAF values increase linearly with AE (Fig. 13). These calculations assumed a constant $K d$ for each element and a TSS load of $5 \mathrm{mg} \mathrm{l}^{-1}$. Se is most affected by $\mathrm{AE}$, with a slope of about 1 (calculated from the regression of change in $\mathrm{AE}$ with
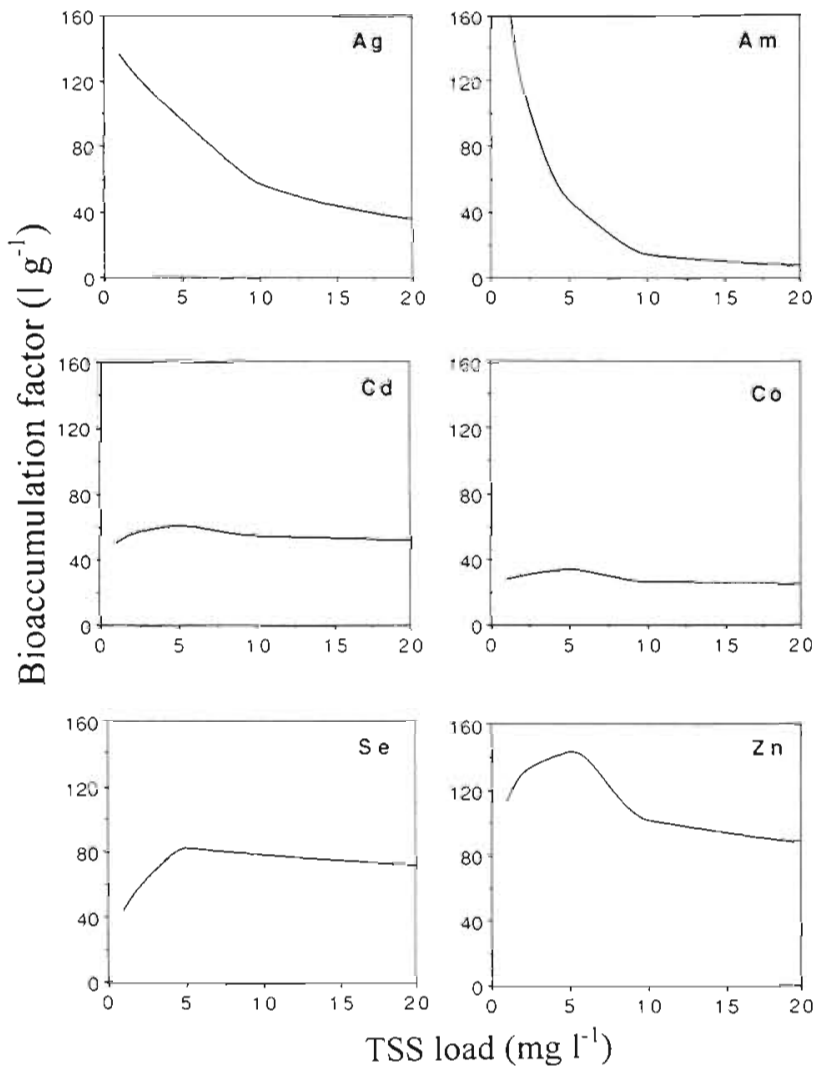

Fig. 12. Mytilus edulis. Predicted bioaccumulation factor (BAF, $1 \mathrm{~g}^{-1}$ dry wt) of 6 trace elements in mussel soft parts at different TSS loads, over a range of 1 to $20 \mathrm{mg}$ dry wt $\mathrm{l}^{-1}$. BAF calculated using Eq. (15) 


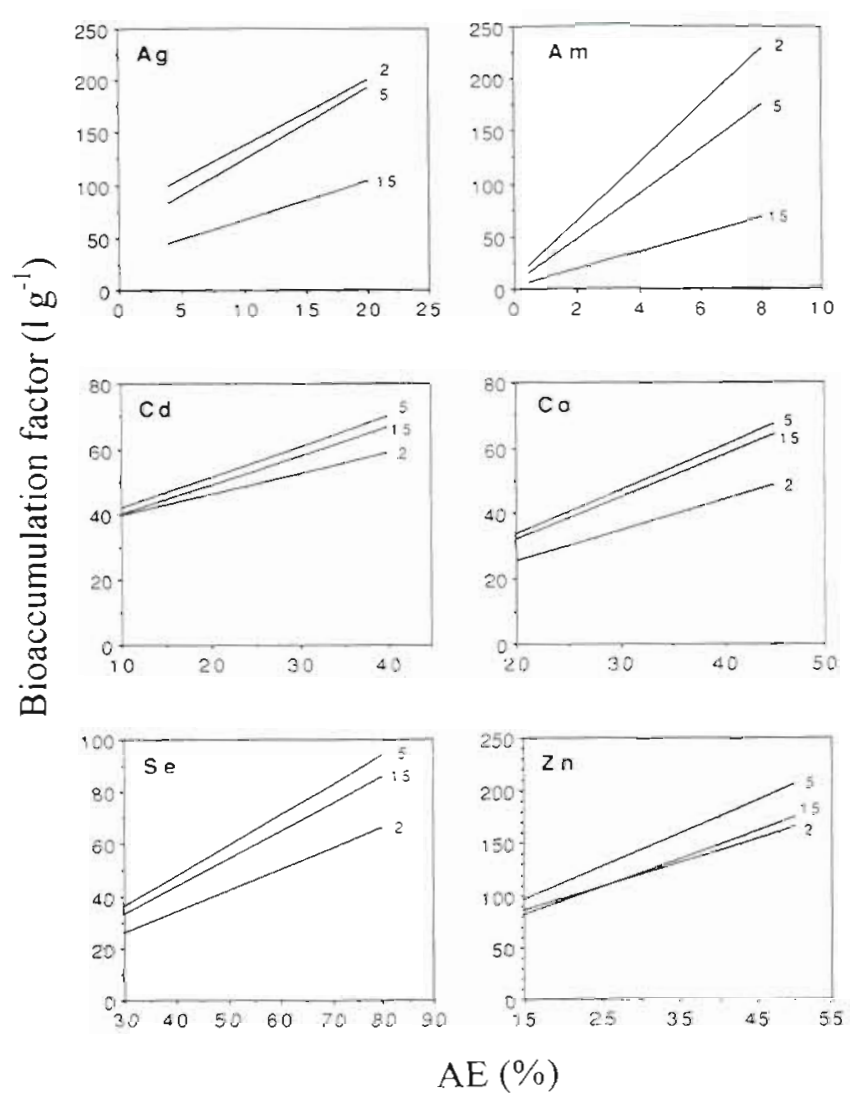

Fig. 13. Mytilus edulis. Relationship of the predicted bioaccumulation factor (BAF, $~^{-1}$ dry $w$ ) of 6 trace elements in mussel soft parts and their AES from ingested particles, for TSS loads of 2, 5, and $15 \mathrm{mg}$ dry wt $1^{-1}$ BAF calculated using Eq. (15)

change in $\mathrm{BAF}$ ). Among the 6 elements, $\mathrm{Cd}$ is the least affected by AE (slopes of 0.2 to 0.3 ). Ag and Am are strongly affected at high TSS loads (slopes of 0.34 for Ag, 0.71 for Am) and less affected at lower TSS loads (slopes of 0.26 for $\mathrm{Ag}, 0.62$ for $\mathrm{Am}$ ) because of the relationship described above. For the other elements, the slopes are about 0.4 to 0.5 for $\mathrm{Zn}$, and 0.7 to 0.8 for $\mathrm{Co}$, respectively.

\section{Salinity}

Salinity can affect both metal influx rate from the dissolved phase and $\mathrm{Kd}$ for suspended particles. Kuwabara et al. (1989) found that the $K d$ s of $\mathrm{Cd}$ and $\mathrm{Zn}$ in South SFB increased by 1.3 and $1.6 \times$, respectively, when the salinity decreased from 32 to $20 \%$. However, variable effects of salinity have been reported for Ag (Smith \& Flegal 1993), Se (Cutter 1989), Cd and Zn (Sung 1995, Wood et al. 1995). We assume that salinity will only affect metal influx rates from the dissolved phase and then calculated the change in BAF for salinities of 20 to 32 (typical of South SFB). These calcula- tions use the median $K d$ and $A E$ for each metal (Fig. 10). By lowering the salinity from 32 to $20 \%$, the estimated BAFs increase by $35 \%$ for $\mathrm{Ag}, 14 \%$ for $\mathrm{Am}$ $38 \%$ for $\mathrm{Cd}, 13 \%$ for $\mathrm{Co}, 1 \%$ for $\mathrm{Se}$, and $24 \%$ for $\mathrm{Zn}$. The relative contribution of dissolved metal uptake will increase from 50 to $63 \%$ for $\mathrm{Ag}$, from 9 to $20 \%$ for Am, from 64 to $74 \%$ for $\mathrm{Cd}$, from 14 to $24 \%$ for $\mathrm{Co}$, from 2 to $3 \%$ for Se, and from 34 to $47 \%$ for $\mathrm{Zn}$. These results suggest that the influence of salinity on metal bioaccumulation in mussels is small compared to other factors.

\section{Partition coefficient}

Variations in $K d$ reflect changes in metal partitioning in the dissolved and particulate phases (and thus metal concentrations in both phases; see Eq. 13). Therefore, metal influx rates from both the dissolved and particulate phases vary with $K d$. We calculated the BAFs for each metal by increasing the $K d 10 \times$ (using the lowest $K d$ for each metal shown in Fig. 10), assuming a $5 \mathrm{mg}$ $\mathrm{I}^{-1}$ TSS load and an intermediate AE for each metal (see Fig. 10). The results indicate that this 10-fold increase in $\mathrm{Kd}$ would lead to BAF increases of $16 \%$ for $\mathrm{Ag}, 22 \%$ for $\mathrm{Am}, 145 \%$ for Cd, $575 \%$ for Co, $694 \%$ for $\mathrm{Se}$, and $280 \%$ for $\mathrm{Zn}$. The smallest effect of $\mathrm{Kd}$ on BAF was for the most particle-reactive elements (Ag and Am) because $C_{w}$ decreases most for these elements with increasing $K d$ values (see Fig. 11). The greatest effect of increasing the $\mathrm{Kd}$ was for $\mathrm{Co}$ and $\mathrm{Se}$. For both elements, which have relatively low $K d$ values, the $\mathrm{C}_{w}$ does not change appreciably as $\mathrm{Kd}$ increases, and $>70 \%$ of the Co and $>96 \%$ of Se is calculated to come from the food (Fig. 10), leading to sharp increases as particulate concentrations increase.

\section{DISCUSSION}

\section{Trace element assimilation from food}

The AEs of the trace elements from natural seston were generally in the lower range of AEs measured for diverse phytoplankton foods, consistent with our previous observation that trace element assimilation is related to the nutritional quality of ingested food particles (Wang \& Fisher 1996a). For example, AEs for algal food range between 4 and $34 \%$ for $\mathrm{Ag}, 0.7$ and $6 \%$ for Am, 11 and $34 \%$ for $\mathrm{Cd}, 20$ and $43 \%$ for Co, 15 and $72 \%$ for $\mathrm{Se}$, and 16 and $48 \%$ for Zn (Wang \& Fisher 1996a). Because natural seston consist of diverse biological and inorganic particles (including algal cells and resuspended sediment), it is unlikely that a single AE for each trace element can be applicable to all natural systems. 
The cytoplasmic distribution directly influenced their assimilation of at least some elements from the natural seston, as observed elsewhere (Reinfelder \& Fisher 1991, 1994). The 1:1 relationship between Se cytoplasmic distribution and its assimilation in mussels was consistent with a previous study showing a 1:1 relationship between the cytological distribution of Se in the diatom Thalassiosira pseudonana and its AE in mussels (Wang \& Fisher 1996b), even though cytoplasmic Se and AEs from seston were lower than those measured from unialgal diets (Wang \& Fisher 1996a). A possible explanation for the low cytoplasmic Se concentration is the shorter labeling period (36 h, under dark conditions), which may limit Se penetration into the algal cytoplasm. This element is mainly associated with soluble amino acids and small polypeptides (Wrench 1978, Fisher \& Reinfelder 1991) in algal cytoplasm. The greatest deviation from the $1: 1$ relationship of $\mathrm{AE}$ and cytoplasmic distribution was found for $\mathrm{Ag}$, Cd, and Zn, consistent with Wang \& Fisher's (1996a) findings for these metals.

\section{Trace element uptake from the dissolved phase}

The present study employed a kinetic approach to determine trace element uptake rate from the dissolved phase. The short term exposure provided a best estimate of gross influx rates, without a pronounced influence from efflux. These influx rates are then suitable for use in a kinetic model. Most previous trace element uptake studies from the dissolved phase exposed mussels from days to weeks in the absence of food particles. In addition to being unsuitable to determine model coefficients (gross influx), biases can occur in long term exposures due to decreased filtration activity (starvation stress) or complexation with mussel metabolites/exudates or mucus. Conducting such experiments to directly determine $C_{s s}$ is also problematic. Time to reach steady state can vary with the trace element and environmental conditions. For example, Regoli \& Orlando (1994) showed that an equilibrium can be achieved in mussels following 2 wh transplantation to contaminated waters, but Tessier et al. (1993) observed that $\mathrm{Cd}$ equilibrium in the freshwater bivalve Anodonta grandis was not reached after $1 \mathrm{yr}$.

The influx rate from the dissolved phase increased linearly with dissolved concentration, as observed in juvenile mussels exposed for longer periods to dissolved Cd over a concentration range of 0.02 to $50 \mu \mathrm{g}$ $\mathrm{l}^{-1}$ (Fischer 1988) and in adult mussels exposed to $\mathrm{Pu}$ and Am (Bjerregaard et al. 1985). However, the kinetic approach provides the first quantitative measurement of dissolved uptake rate constants $\left(k_{\mathrm{u}}\right)$ for trace elements in mussels. The uptake rate constant is a func- tion of a mussel's filtering activity and absorption efficiency from the dissolved phase. Within a species, values of $k_{\mathrm{u}}$ represent the relative assimilability of trace elements from the dissolved phase. Because they are physiologically mechanistic, the constants can be objectively compared among species (if differences in filtration rates are known), elements, or environmental conditions. In mussels, the $k_{u}$ values differed widely among trace elements, with $\mathrm{Ag}>\mathrm{Zn}>\mathrm{Am} \approx \mathrm{Cd}>\mathrm{Co}>$ Se. This is consistent with observations in the polychaete Nereis diversicolor in which uptake rates decrease in the order of $\mathrm{Hg}>\mathrm{Cu}>\mathrm{Ag}>\mathrm{Cr}=\mathrm{Pb}>\mathrm{Zn}>$ $\mathrm{Cd}>\mathrm{Ni}>\mathrm{Co}$, Se (Bryan 1984). Ag, Zn and Cd can bind strongly with sulfur groups in protein and show the greatest propensity for transport across membranes. Strong binding of these metals with intracellular pools such as metallothioneins may also increase their removal from ambient aqueous environments. In addition, the high $k_{\mathrm{u}}$ of Ag may be explained by its speciation in marine waters, which is dominated by a $\mathrm{AgCl}^{0}$ neutral charge complex (Turner et al. 1981, Byrne et al. 1988). This complex is very bioavailable to marine organisms due to its low polarity (Engel et al. 1981).

It is also notable that the absorption efficiencies from the dissolved phase estimated here are significantly lower than the assimilation efficiencies from food. However, given their high filtration rates (52 to $196 \mathrm{l}$ $\mathrm{g}^{-1} \mathrm{~d}^{-1}$; Widdows et al. 1995), mussels process large volumes of water, and so uptake from the dissolved phase may contribute significantly to metal accumulation in mussels. We are aware of no direct measurements of metal absorption efficiencies from the dissolved phase in marine bivalves.

The increase observed in metal influx rates at lower salinities is consistent with many previous reports (Phillips 1976, Jackim et al, 1977, Fischer 1986, 1988, Bjerregaard \& Depledge 1994), however salinity had a smaller effect than other factors studied here. Other reports have suggested that changes in metal speciation are responsible for greater uptake rates at lower salinities (Wright 1995). Many studies have demonstrated that the free metal ion is the most bioavailable form in aquatic organisms, including marine mussels (Bjerregaard \& Depledge 1994, Campbell 1995). In the present study, the observed increase in element uptake with decreasing salinity was similar for all trace elements that change speciation at low salinity (Ag, $\mathrm{Cd}$, and $\mathrm{Zn}$ ) and for elements that do not (Turner et al. 1981, Byrne et al. 1988). Se may be considered as a 'control' to monitor the influence of free ion on metal uptake at different salinities. Se was added in selenite form, which does not speciate differently at different salinities. Influx rates of $\mathrm{Se}$, as well as those of $\mathrm{Ag}, \mathrm{Cd}$, Co and $\mathrm{Zn}$, increased 1.6 to 1.9 times when the salinity decreased from 34 to $20 \%$. When the salinity was fur- 
ther lowered to $15 \%, \mathrm{Ag}$ and $\mathrm{Cd}$ exhibited influx rate decreases similar to Se. In fact, salinity change in the 15 to $35 \%$ range has only a small influence on free ion concentrations of trace metals, so trace element speciation may not be the best explanation for the observed decrease in metal influx at high salinity. Wright \& Zamuda (1987) also showed that the salinity effect can be independent of $\mathrm{Cu}$ free ion activity in seawater. They maintained a relatively constant $\mathrm{Cu}$ free ion activity at different salinities, and measured its accumulation in oysters Crassostrea virginica and clams Mya arenaria. Both species accumulated significantly more $\mathrm{Cu}$ at lower salinity (but at constant ionic activity), indicating that the salinity effect is independent of Cu free ion activity in seawater.

A possible mechanism underlying the increased influx at low salinity is the decreasing osmolarity and increasing cell membrane permeability at lower salinities (Chan et al. 1992). George et al. (1978) demonstrated that a decrease in osmolarity was responsible for an increase in Cd uptake in mussels at low salinities. When the osmolarity was held constant, $\mathrm{Cd}$ uptake was independent of salinity over a range of 15 to $35 \%$.

No significant difference in influx rate was detected at different concentrations of DOM and for different batches of seawater. The UV irradiation only removed about $50 \%$ of the DOM from the seawater, and this may not have been sufficient to result in a significant change in free ion activity. However, Zamuda et al. (1985) showed that over a $24 \mathrm{~h}$ exposure to $10 \mu \mathrm{g}$ $\mathrm{Cu}^{-1}$, the $\mathrm{Cu}$ accumulation rate in oysters Crassostrea virginica doubled when the seawater was UV irradiated (removing $50 \%$ of the DOM). Absil et al. (1993) also found that metal complexation by natural ligands was important in reducing $\mathrm{Cu}$ bioavailability to Macoma balthica exposed to dissolved $\mathrm{Cu}$ for $28 \mathrm{~d}$, with Cu uptake rates decreasing by $>50 \%$ when DOM levels increased by $>5$-fold

\section{Trace element efflux}

Depuration patterns for whole mussels (soft parts and shell) of the trace elements were characterized by 1 to 3 compartments, consistent with many previous observations in marine bivalves (Young \& Folsom 1967, Dahlgaard 1981, 1986, Bjerregaard et al. 1985). The first compartment was probably dominated by egestion of unassimilated materials and rapid desorption of surface bound material. The depuration of $\mathrm{Cd}$ after 6 or $7 \mathrm{~d}$ of uptake from food or the dissolved phase, however, indicated that this element was evident in only 1 compartment, perhaps reflecting its sequestration principally by metallothionein.
Fowler et al. (1975) demonstrated that the excretion kinetics of ${ }^{65} \mathrm{Zn}$ in the shrimp Lysmata seticauda was dependent on the route of $\mathrm{Zn}$ exposure, due to different equilibration times of ${ }^{65} \mathrm{Zn}$ with stable $\mathrm{Zn}$ pools in the animals. Neither exposure time (12 h vs $6 \mathrm{~d}$ ) nor route of uptake (dissolved vs food) had a significant. effect on the efflux rate in mussels in our study, suggesting that radiotracers were able to partition rapidly into the slowest compartment. The proportion of radioisotope in the slowest compartment, however, increased with duration of exposure, as observed in many other studies (Cutshall 1974, Amiard 1978, Nugegoda \& Rainbow 1989).

The efflux rate constant of Ag was greater after particulate ingestion than after uptake from the dissolved phase, in contrast to the bivalve Scrobicularia plana, in which Amiard (1978) found that ${ }^{110 \mathrm{~m}} \mathrm{Ag}$ was lost faster following uptake from the dissolved phase. The difference in Ag efflux may be due to its binding with different ligands, as shown in oysters (Berthet et al. 1992). Specifically, Ag from food may bind with metal-rich granules $\left(\mathrm{Ag}_{2} \mathrm{~S}\right)$ in the cell lining of the digestive tract, which then release Ag into the gut lumen for egestion by defecation. Ag accumulated from the dissolved phase may be stored in the kidneys in insoluble form (George et al. 1986), and then excreted at a rate slower than Ag defecation. Our unpublished data also suggest that excretion was the major pathway of Ag physiological loss after dissolved uptake, whereas defecation was dominant after food uptake.

The biological half-lives of the 6 trace elements in the mussels measured in this study were within the range of values measured in previous studies (Table 9). It is difficult to directly compare efflux rates among different studies because different investigators often employ different experimental conditions, some or all of which may strongly influence efflux rates. Recently. Fisher et al. (1996) showed that efflux rates of 7 trace elements from the mussel Mytilus galloprovincialis in the laboratory and in the field are directly comparable, particularly for mussel soft parts.

\section{Modeling trace element bioaccumulation in mussels}

The kinetic modeling approach allows an assessment of the effects of changes in geochemical and biological factors on the bioaccumulation of various metals. Our kinetic model predicted metal concentrations in marine mussels that are comparable to concentrations measured in various monitoring programs, suggesting that metal accumulation in mussels can be accurately predicted using the physiological and geochemical parameters identified in the kinetic model. It is clear that 2 physiological parameters, metal absorp- 
Table 9. Comparison of biological half-lives $\left(\mathrm{tb}_{1 / 2}\right)$ of trace elements in whole mussels (shell and soft parts) from various studies. M.e.: Mytilus edulis; M. c.: Mytilus californianus; M.g.: Mytilus galloprovincialls

\begin{tabular}{|c|c|c|c|c|}
\hline Element & $\mathrm{tb}_{1 / 2}(\mathrm{~d})$ & Species & Condition & Source \\
\hline $\mathrm{Ag}$ & $22-38$ & M.e. & Laboratory depuration & This study \\
\hline Ag & $45-58$ & M.e. & Field depuration & Dahlgaard (1986) \\
\hline $\mathrm{Ag}$ & 17 & $M . g$ & Ficld depuration & Whitehead et al. (1988) \\
\hline $\mathrm{Ag}$ & $24-27$ & $M \cdot g$ & Field depuration & Fisher et al. (1996) \\
\hline $\mathrm{Ag}$ & $4-25$ & $M . g$. & Laboratory depuration & [isher et al. (1996) \\
\hline Am & $35-39$ & Me. & Laboratory depuration & This study \\
\hline Am & 88 & Me. & Laboratory depuration & Bjerregaard et al. (1985) \\
\hline Am & 300 & Me. & Field depuration & Clifton et al. (1983) \\
\hline Am & 480 & $M, g$ & Field depuration & Guary \& Fowler (1981) \\
\hline Am & $14 \hat{1}-195$ & Me. & Field depuration & Dahlgaard (1986) \\
\hline Am & $38-64$ & M.g. & Field depuration & Flsher et al. (1996) \\
\hline Am & $15-61$ & $M . g$. & Laboratory depuration & Fisher et al. (1996) \\
\hline $\mathrm{Cd}$ & $67-78$ & Me. & Laboratory depuration & This study \\
\hline $\mathrm{Cd}$ & 1155 & $M g$ & Laboratory depuration & Fowler \& Benayoun (1974) \\
\hline $\mathrm{Cd}$ & 347 & $M . g$ & Field depuration & Fowler \& Benayoun (1974) \\
\hline $\mathrm{Cd}$ & 104 & Me. & Food ingestion & Borchardt (1983) \\
\hline $\mathrm{Cd}$ & $122-190$ & M.e. & Dissolved uptake & Borchardt (1983) \\
\hline $\mathrm{Cd}$ & $46-822$ & $M . g$ & Field depuration & Fisher et al. (1996) \\
\hline $\mathrm{Cd}$ & $16-60$ & $M . g$ & Laboratory depuration & Fisher et al. (1996) \\
\hline $\mathrm{Co}$ & $45-72$ & M.e. & Laboratory depuration & This study \\
\hline $\mathrm{Co}$ & 580 & M.e. & Field depuration & Dahigaard (1981) \\
\hline Co & $57-72$ & Me. & Laboratory depuration & Van Weers (1973) \\
\hline $\mathrm{Co}$ & $79-88$ & M.e. & Field depuration & Dahlgaard \{1986\} \\
\hline Co & $55-65$ & $M g$. & Field depuration & Fisher et al. (1996) \\
\hline Co & $12-35$ & M.g. & Laboratory depuration & Fisher et al. (1996) \\
\hline $\mathrm{Se}$ & $28-39$ & M.e. & Laboratory depuration & This study \\
\hline $\mathrm{Se}$ & 81 & $M . g$ & Field depuration & Fowler \& Benayoun (1976) \\
\hline $\mathrm{Zn}$ & $44-66$ & Me. & Laboratory depuration & This study \\
\hline $\mathrm{Zn}$ & 82 & M.c. & Field transplantation & Young \& Folsom (1967) \\
\hline $\mathrm{Zn}$ & 87 & M.e. & Field depuration & Dahlgaard (1986) \\
\hline $\mathrm{Zn}$ & $48-60$ & M.e. & Laboratory depuration & Van Weers (1973) \\
\hline $\mathrm{Zn}$ & 67 & M.e. & Field depuration & Dahlgaard (1986) \\
\hline $\mathrm{Zn}$ & $41-52$ & M.g. & Field depuration & Fisher et al. (1996) \\
\hline $\mathrm{Zn}$ & $11-1291$ & M.g. & Laboratory depuration & Fisher et al. (1996) \\
\hline
\end{tabular}

tion efficiency from the dissolved phase and assimilation efficiency from the particulate phase, are critical criteria in assessing metal bioavailability to aquatic animals.

\section{Cadmium}

Under the different conditions that can occur in SFB, the kinetic model predicted that $C d$ concentrations in mussels would vary from 2.7 to $10.1 \mathrm{\mu g} \mathrm{g}^{-1}$, a range remarkably similar to that observed in the NS\&T monitoring program. A change in food sources that caused AE to shift from 0.1 to 0.3 would cause a $1.5 \times$ increase in tissue concentrations ( 2.7 vs $4.5 \mu \mathrm{g} \mathrm{g}^{-1}$ ). If the highest dissolved concentrations occurred during reduced salinity when a food source was present with highly bioavailable $\mathrm{Cd}$, the maximum tissue burden expected in mussels in the Bay would be about $10.1 \mu \mathrm{g} \mathrm{g}{ }^{1}$.

In the above scenario for SFB, uptake of dissolved Cd was calculated to contribute $>50$ to $80 \%$ of the total $\mathrm{Cd}$ burden in mussel tissues. Estimates of the relative importance of Cd uptake from food and solution have varied in previous studies. Borchardt (1983) used ${ }^{109} \mathrm{Cd}$ and ${ }^{115} \mathrm{Cd}$ to radiolabel algal cells and water, respectively, and then measured the relative accumulation of these 2 isotopes in mussel tissues. The Cd concentration he derived from food uptake was $<1 \%$ of the total $\mathrm{Cd}$ accumulated. Other studies also concluded that uptake of particulate Cd contributed $<10 \%$ of the total Cd body burden in mussels (Janssen \& Scholz 1979, Riisgard et al. 1987). These measurements examined only 1 food species. Thomann et al. (1995), using a steady-state model of mussel accumulation of metals, concluded that $>90 \%$ of $\mathrm{Cd}$ is obtained from ingested food particles; they used only $1 \mathrm{AE}$ value for each metal, 1 IR value and, lacking direct data on uptake rates from the dissolved phase, used bioconcentration factors to estimate influx from the dissolved phase.

Cossa (1988) summarized a linear relationship between $\mathrm{Cd}$ concentration in mussel tissue and $\mathrm{Cd}$ concentration in seawater from various coastal loca- 
tions, which can be described by $C\left(\mu \mathrm{g} \mathrm{g}^{-1}\right)=0.074 \times$ $C_{\mathrm{w}}\left(\mathrm{ng} \mathrm{l}^{-1}\right)+0.390$, where $C_{\mathrm{w}}$ is the Cd concentration in seawater and $C$ is the $C d$ concentration in mussel tissues. Of course, such a correlation does not necessarily mean that all $\mathrm{Cd}$ uptake was from seawater. The kinetic model projected concentrations very similar to the calculation from his empirical relationship, especially using a $K d$ value of $5 \times 10^{3}$ and an AE of $40 \%$ or a $K d$ value of $10^{4}$ and an $\mathrm{AE}$ of $20 \%$. The model predicted that $45 \%$ of $\mathrm{Cd}$ in mussels was obtained from ingestion of food and $55 \%$ via uptake from water in these situations.

Selenium

Modeling Se accumulation based only on selenite uptake adequately explained the Se concentration in field-collected mussels because virtually all of the Se should be accumulated from ingested food (>96\%). Luoma et al. (1992) showed that Se concentrations in the clam Macoma balthica in SFB could be accounted for primarily by assimilation of Se from ingested food, consistent with other observations of Se accumulation in aquatic invertebrates (Fowler \& Benayoun 1976, Zhang et al. 1990). The dominance of Se uptake from food is mainly due to the slow uptake rate from the dissolved phase and the high assimilation efficiency. The calculated dissolved uptake constant for Se was 4 to $50 \times$ lower than the other 5 elements. The ultimate source of Se for mussels is probably selenite, but first it must be accumulated out of the dissolved phase by phytoplankton (Fisher \& Reinfelder 1991).

Zinc

At low dissolved $\mathrm{Zn}$ concentrations $\left(0.5 \mu \mathrm{g} \mathrm{I}^{-1}\right)$, the projected $\mathrm{Zn}$ concentration in mussel tissues at Dumbarton Bridge station is within the range of values measured in monitoring programs, whereas at high $\mathrm{Zn}$ concentrations $\left(1.7 \mathrm{\mu g} \mathrm{l}^{-1}\right.$; Flegal et al. 1991), the projected mussel concentration exceeds measured concentrations, especially when using high estimates of AE (Table 8). It is noteworthy, however, that higher $\mathrm{Zn}$ concentrations (120 to $\left.340 \mu \mathrm{g} \mathrm{g}^{-1}\right)$ in mussels were measured at the Emeryville Station in SFB (T. P. $\mathrm{O}^{\prime}$ Connor pers. comm.). However, the predicted $\mathrm{Zn}$ concentrations ( 34 to $157 \mu \mathrm{Hg} \mathrm{g}^{-1}$ ) in LIS are fully within the range of actual concentrations (52 to $142 \mu^{-1} \mathrm{~g}^{-1}$ ) measured by the Mussel Watch Program (Goldberg et al, 1983)

The relative contribution of $\mathrm{Zn}$ predicted from food uptake was about 50 to $72 \%$ under different environmental scenarios. Thomann et al. (1995), using the same approach as for Cd uptake (see above), estimated that $>90 \%$ of $\mathrm{Zn}$ in mussels is accumulated from food. Our model indicates that $K d$ is a critical parameter affecting the relative importance of each uptake pathway for $\mathrm{Zn}$. The relative uptake from the dissolved phase decreases by $2.8 \times$ when the $K d$ increases by $5 \times$. In this model, we employed a moderate range of $K d$ for Zn (1 to $5 \times 10^{4}$; Balls 1989, Kuwabara et al. 1989, Benoit et al. 1994), comparable to its concentration factor in phytoplankton (Fisher \& Reinfelder 1995), but lower than recent unpublished measurements in SFB (B.-G. Lee, A. van Geen \& S. Luoma unpubl.).

Silver

A varying contribution from the dissolved phase was noted for Ag (30 to $70 \%$ ) in our study. Because this metal is very particle-reactive and exhibits variable partitioning in natural seston, $K d$ plays the most significant role in the relative importance of uptake of dissolved Ag Other experimental studies suggested that Ag was taken up by grass shrimp Paleomonetes pugio and oysters Crassostrea virginica and C. gigas mainly from the dissolved phase (Martoja et al. 1988, Abbe \& Sanders 1990, Connell et al. 1991). Abbe \& Sanders (1990) showed that oysters did not accumulate Ag from sediments or from algal food during a 14 to 21 d uptake period. In their study, desorption of Ag from ingested particles was not important in removing Ag from ingested particles, thus most Ag ingested by the oysters was subsequently egested as feces. The variable results of such studies suggest that environmental conditions may determine which pathway(s) of Ag dominate uptake, even more so than for other elements.

Americium and cobalt

There have been a few measurements of Am and Co concentrations in seawater or in mussels, but not both, in the same time and place (Goldberg et al. 1983, Flegal et al. 1991, Valette-Silver \& Lauenstein 1995), so we cannot at present use our model to predict concentrations of these metals in the field. Although the influx rate of Am from the dissolved phase was high and its AE from food was low, its very high $K d$ results in a low dissolved concentration, and therefore the particulate phase is more important than the dissolved phase $(4: 1)$ in Am accumulation in mussels. For $\mathrm{Co}$, the dominance of the particulate pathway may be attributed to its low dissolved influx rate and high $\mathrm{AE}$.

In summary, this study demonstrates that the kinetic model can be used to describe trace element bioaccu- 
mulation in mussels. Rate constants (e.g. for influx and efflux) determined in the laboratory are valuable for understanding and predicting metal accumulation in marine bivalves. Although the data required by this model are relatively extensive, the model is robust in that it can incorporate various environmental conditions that may affect metal bioaccumulation, such as temperature, salinity, dissolved organic matter, and seston load. Furthermore, it avoids problems typically associated with an equilibrium approach in describing metal accumulation in aquatic animals. Comparison of influx rate constants for various uptake pathways enables a direct estimation of the relative importance of each uptake pathway. Our calculations illustrate that trace elements vary widely in their accumulation patterns in mussels and that both dissolved and particulate metals are appreciably accumulated in mussels. Water quality criteria based solely on dissolved metal concentrations are therefore inadequate to assess metal bioavailability to marine bivalves. The relative importance of each source is principally related to metal partitioning in food particles, metal assimilation efficiency and to a lesser degree, the seston load. Other factors may also affect the contribution from each source by influencing the influx rate (e.g. the effects of salinity on the influx rate from the dissolved phase). The model demonstrates that the total concentration of trace element in the water column $\left(C_{1}\right)$, the assimilation efficiency in the mussels (AE), and the seston load (TSS) are all major parameters determining metal accumulation in mussels. Thus, with this model it is possible to further elucidate rates and routes of metal accumulation in mussels, and this information can be used to interpret the voluminous data being generated by national monitoring programs.

Acknowledgements. We are most grateful to Dr T. O'Connor for providing us with NS\&T data on mussel concentrations of metals and to Dr R. Thomann for helpful discussions. This research was supported by grants from the US EPA (R81947201), the New York Sea Grant Institute (NA90AADSG078 and NA46RG0090), and the National As5ociation of Photographic Manufacturers to N.S.F. This is MSRC Contribution No. 1015.

\section{LITERATURE CITED}

Abbe GR, Sanders JG (1990) Pathways of silver uptake and accunulation by the American oyster (Crassostrea virgunica) in Chesapeake Bay. Estuar Coast Shelf Sci 31:113-123

Absil MCP, Gerringa LJA, Wolterbeck B (1993) The relation between salinity and copper complexing capacity of natural estuarine waters and the uptake of dissolved ${ }^{64} \mathrm{Cu}$ by Macoma balthica. Chem Speciation Bioavailability 5: $119-128$

Amiard JC (1978) Modalités de la contamination d'une chaine trophique marine benthique par l'argent $110 \mathrm{~m}$. 4. Influence du mode de contamination sur l'élimination du radionucléide. J Exp Mar Biol Ecol 34:215-225
Armstrong FA, Williams PM, Strickland JD (1966) Photooxidation of organic matter in seawater by ultraviolet radiation, analytical and other applications. Nature 211:481-487

Balls PW (1989) The partitioning of trace metals between dissolved and particulate phases in European coastal waters: a compilation of field data and comparison with laboratory studies. Neth J Sea Res 23:7-14

Bayne BL (1993) Feeding physiology of bivalves: time-dependence and compensation for changes in food availability. In: Dame RF (ed) Bivalve filter feeders in estuarine and coastal ecosystem processes. Springer-Verlag, Berlın, p $1-24$

Bayne BL, Hawkins AJS, Navarro E (1987) Feeding and digestion by the mussel Mytilus edulis L. (Bivalvia: Mollusca) in mixtures of silt and algal cells at low concentrations. J Exp Mar Biol Ecol 111:1-22

Bayne BL, Iglesias JIP, Hawkins AJS, Navarro E, Heral M. Deslous-Paoli JM (1993) Feeding behavior of the mussel, Mytilus edulis: responses to variations in quantity and organic content of the seston. J Mar Biol Ass UK 73: $813-829$

Benoit G, Oktay-Marshall SD, Cantu A, Hood EM, Coleman $\mathrm{CH}$, Corapcioglu MO. Santschi PH (1994) Partitioning of $\mathrm{Cu}, \mathrm{Pb}, \mathrm{Ag}, \mathrm{Zn}, \mathrm{Fe}, \mathrm{Al}$, and $\mathrm{Mn}$ between filter-retained particles, colloids, and solution in six Texas estuaries. Mar Chem 45:307-336

Berthet B, Amiard JC, Amiard-Triquet C, Martoja M, Jeantet $A Y$ (1992) Bioaccumulation, toxicity and physico-chemical speciation of silver in bivalve molluscs: ecotoxicological and health consequences. Sci Total Environ 125:97-122

Bjerregaard P, Depledge $\mathrm{MH}$ (1994) Cadmium accumulation in Littorina Littorea, Mytilus edulis and Carcinus maenas: the influence of salinity and calcium ion concentrations. Mar Biol 119:385-395

Bjerregaard P, Topçuoğlu S, Fisher NS, Fowler SW (1985) Biokinetics of americium and plutonum in the mussel Mytilus edulis. Mar Ecol Prog Ser 21:99-111

Boese BL, Lee H, Specht DT, Randall RC. Winsor M (1990) Comparison of aqueous and solid phase uptake for hexachlorobenzene in the tellinid clam, Macoma nasuta (Conrad): a mass balance approach. Environ Toxicol Chem 9: $221-231$

Borchardt T (1983) Influence of food quantity on the kinetics of cadmium uptake and loss via food and seawater in Mytilus edulis. Mar Biol 76:67-76

Breck JE, Bartell SM (1988) Approaches to modeling the fate and effects of toxicants in pelagic systems. In: Evans MS (ed) Toxic contamuants and ecosystem health: a Great Lake focus. John Wiley \& Sons, New York, p 427-446

Bryan GW (1984) Pollution due to heavy metals and their compounds. In: Kinne O (ed) Marine ecology, Vol 5. John Wiley \& Sons, Chichester, p 1289-1430

Byrne RH, Kump LR, Cantrell KJ (1988) The influence of temperature and $\mathrm{pH}$ on trace metal speciation in seawater. Mar Chem 25:163-181

Campbell PGC (1995) A critique of the free-1on activity model In: Tessier A, Turner DR (eds) Metal speciation and bioavailability in aquatic systems. John Wiley \& Sons, Chichester, p 45-102

Chan HM, Bjerregaard P, Rainbow PS, Depledge MH (1992) Uptake of zinc and cadmium by two different populations of shore crabs Carcinus maenus at different salinities. Mar Ecol Prog Ser 86:91-97

Clifton RJ, Stevens HE, Hamilton EI (1983) Concentration and depuration of some radionuclides present in a chronically exposed population of mussel (Mytilus edulis). Mar Ecol Prog Ser 11:245-256 
Connell DB, Sanders JG, Riedel GF, Abbe GR (1991) Pathways of silver uptake and trophic transfer in estuarine organisms. Environ Sci Technol 25:921-924

Connolly JP (1991) Application of a food chain model to polychlorinated biphenyl contamination of the lobster and winter flounder food chains in Vew Bedford Harbor. Environ Sci Technol 25:760-770

Cossa D (1988) Cadmium in Mytilus spp.: worldwide survey and relationship belween seawater and mussel content Mar Environ Res 26:265-284

Cutshall N (1974) Turnover of zinc-65 in oysters. Health Phys $26: 327-331$

Cutter GA (1989) The estuarine behavior of selenium in San Francisco Bay. Estuar Coast Shelf Sci 28:13-34

Cutter GA. Bruland KW (1984) The marine biogeochemistry of selenium: a re-evaluation. Limnol Oceanogr 29 $1179-1192$

Dahlgaard $\mathrm{H}$ (1981) Loss of ${ }^{51} \mathrm{Cr},{ }^{51} \mathrm{nn},{ }^{57} \mathrm{Co},{ }^{54} \mathrm{Fe},{ }^{65} \mathrm{Zn}$ and ${ }^{134} \mathrm{Cs}$ by the mussel Mytilus edulis. In: IAEA (ed) Proc Symp impacts of radionuclide releases into the marine environment. IAEA, Vienna, p 361-370

Dahlgaard $H$ (1986) Effects of season and temperature on long-term in situ loss rates of $\mathrm{Pu}, \mathrm{Am}, \mathrm{N}_{\mathrm{p}}, \mathrm{Eu}, \mathrm{Ce}, \mathrm{Ag}, \mathrm{Ic}$, $\mathrm{Zn}, \mathrm{Co}$ and $\mathrm{Mn}$ in a Baltic Mytilus edulis population. Mar Ecol Prog Ser 33:157-165

DiToro DM, Zarba CS, Hansen DJ, Berry WJ, Swartz RC Cowan CE, Pavlou SP, Allen HE, Thomas NA, Paquin PR (1991) Technical basis for establishing sediment quality criteria for nonionic organic chemicals using equilibrium partitioning. Environ Toxicol Chem 10 $1541-1583$

Engel DW, Sunda WG, Fowler BA (1981) Factors affecting trace metal uptake and toxicity to estuarine organisms. In: Vernberg JF, Calabrese A. Thurberg FP, Vernberg WB (eds) Biological monitoring of marine pollutants. Academic Press, New York, p 127-144

Fischer $\mathrm{H}$ (1986) Influence of temperature, salinity, and oxygen on the cadmium balance of mussels Mytilus edulis. Mar Ecol Prog Ser 32:265-278

Fischer $\mathrm{H}$ (1988) Mytilus edulis as a quantitative indicator of dissolved cadmium. Final study and synthesis. Mar Ecol Prog Ser 48:163-174

Fisher NS, Bjerregaard P, Fowler SW (1983a) Interactions of marine plankton with transuranic elements. 1 . Biokinetics of neptunium, plutonium, americium, and californium in phytoplankton. Limnol Oceanogr 28:432 447

Fisher NS, Burns KS, Cherry RD, Heyraud M (1983b) Accumulation and cellular distribution of ${ }^{241} \mathrm{Am},{ }^{210} \mathrm{Po}$, and ${ }^{210} \mathrm{~Pb}$ in two marine algae. Mar Ecol Prog Ser 11:233-237

Fisher NS, Reinfelder JR (1991) Assimilation of selenium in the marine copepod Acartia tonsa studied with a radiotracer ratio method. Mar Ecol Prog Ser 70:157-1.64

Fisher NS, Reinfelder JR (1995) The trophic transfer of metals in marine systems. In: Tessier A, Turner DR (eds) Metal speciation and bioavailability in aquatic systems. John Wiley \& Sons, Chichester, p 363-406

Fisher NS, Teyssie JL, Fowler SW, Wang WX (1996) The accumulation and retention of metals in mussels from food and water: a companson under field and laboratory conditions. Environ Sci Technol 30:in press

Flegal AR, Smith GJ, Gill GA, Sanud.o-Withelmy S, Anderson LCD (1991) Dissolved trace element cycles in the San Francisco Bay estuary. Mar Chem 36:329-363

Fowler SW, Benayoun G (1974) Experimental studies on cadmium flux through marine biota. In: IAEA (ed) Comparative studies of food and environmental contamination. IAEA, Vienna, p 159-178
Fowler SW, Benayoun G (1976) Influence of environmental factors on selenium flux in two marme invertebrates. Mar Biol 37:59-68

Fowler SW, La Rosa J, Heyraud M. Renfro WC (1975) Effect of different radiotracer labelling techniques on radionuclide excretion from marine organisms. Mar Biol 30: $297-304$

George SG. Carpene E. Coombs TL (1978) The effects of salinity on the uptake of cadmium by the common mussel, Mytilus edulis (L.). In: McLusky DS, Berry AJ (eds) Physiology and behavior of marine organisms. Pergamon Press, Oxford, p 189-193

George SG, Purie BJS, Calabrese A, Nelson DA (1986) Biochemical and ultrastuctural observations of long-term silver accumulation in the mussel Mytilus edulss. Mar Env1ron Res 18:255-265

Goldberg ED, Koide M, Hodge V, Flegal AR, Martin J (1983) U.S. mussel watch: 1977-1978 results on trace metals and radionuclides. Estuar Coast Shelf Sc1 16:69-93

Guary JC, Fowler SW (1981) Americium-241 and plutonium237 turnover in mussel (Mytilus galloprovincialis) living in field enclosures. Estuar Coast Shelf Sc1 12:193-203

linnt CD (1979) The role of phytoplankton and particulate organic carbon in trace metal. deposition in Long Island Sound. PhD dissertation, University of Connecticut, Storrs

IAEA (1985) Sediment $K d s$ and concentration factors for radionuclides in the marine environment. IAEA, Vienna

Jackim E, Morrison G, Steele R (1977) Effects of environmental factors on radiocadmium uptake by four species of marine bivalves. Mar Biol 40:303-308

Janssen HH, Scholz N (1979) Uptake and cellular distribution of cadmium in Mytilus edulis. Mar Biol 55:133-141

Kuwabara JS, Chang CCY, Cloern JE, Fries TL, Davis JA, Luoma SN (1989) Trace metal associations in the water column of South San Francisco Bay, California. Estuar Coast Shelf Sci 28:307-325

Landrum PF, Lee FI, Lydy MJ (1992) Toxucokinetics in aquatic systems: model compansons and use in hazard assessment. Environ Toxicol Chem 11:1709-1725

Lee BG, Fisher NS (1994) Effects of sinking and zooplankton grazing on the release of elements from planktonic debris. Mar Ecol Prog Ser 110:271-281

Luoma SN (1989) Can we determine the biological availability of sediment-bound trace elements? Hydrobiol 176/177. $379-396$

Luoma SN, Dagovitz R, Axtmann E (1990) Temporally intensive study of trace metals in sediments and bivalves from a large river-estuarine system: Suisun Bay/Delta in San Francisco Bay. Sci Total Environ 97/98:685-712

Luoma SN, Fisher ViS (1996) Uncertainties in assessing contaminant exposure from sediments. In: Biddinger GR, Dillon $T$. Ingersoll CG (eds) Ecological risk assessments of contaminated sediments. SETAC Spec Publ Series, Pensacola, FL

Luoma SN, Johns C, Fisher NS, Steinberg NS, Oremland RS, Reinfelder JR (1992) Determination of selenium bioavailability to a benthic bivalve from particulate and solute pathways. Environ Sci Technol 26:485-491

Martoja R, Ballan-Dufrançais C, Jeantet AY, Gouzerh P, Am1ard JC, Amiard-Triquet C, Berthet B (1988) Effets chimiques et cytologiques de la contamination expérimentale de l'huitre Crassostrea gigas Thunberg par l'argent administré sous forme dissoute et par voie alimentaire Can J Fish Aquat Sci 45:1827-1841

Mount ME, Sheaffer MK, Abbot DT (1994) Estimated inventory of radionuclides in former Soviet Union naval reactors dumped in the Kara Sea. Arctic Res LS 8:160-178 
Newman MC (1995) Quantitative methods in aquatic ecotoxicology. Lewis Publishers, Boca Raton, FL

Nieboer E, Richardson DH (1980) The replacement of the nondescript term 'heavy metals' by a biological and chemically significant classification of metal ions. Environ Pollut Ser B Chem Phys 1:3-26

Nugegoda D, Rainbow PS (1989) Salinity, osmolality, and zinc uptake in Palaemon elegans (Crustacea: Decapoda). Mar Ecol Prog Ser 55:149-157

O'Connor TP (1992) Recent trends in coastal environmental quality: results from the first five years of the NOAA mussel watch project. US Dept Commerce. NOAA, National Ocean Service, Washington, DC, p 46

O'Connor TP (1996) Trends in chemical concentrations in mussels and oysters collected along the US coast from 1986 to 1993. Mar Environ Res 41:183-201

O'Connor TP, Cantillo AY, Lauenstein GG (1994) Monitoring of temporal trends in chemical contamination by the NOAA national status and trends mussel watch project. In: Kramer KJM (ed) Biomonitoring of coastal waters and estuaries. CRC Press, Boca Raton, FL, p 29-45

Park PK, Kester DR, Duedall IW, Ketchum BH (1983) Radioactive wastes and the ocean: an overview. In: Park PK, Kester DR, Duedall IW, Ketchum BH (eds) Wastes in the ocean, Vol 3, Radioactive wastes in the ocean. John Wiley \& Sons, New York, p 3-46

Parsons TR, Maita Y, Lalli CM (1984) A manual of chemical and biological methods for seawater analysis. Pergamon Press, Oxford

Phillips DJH (1976) The common mussel Mytilus edulis as an indicator of pollution by zinc, cadmium, lead and copper. I. Effects of environmental variables on uptake of metals. Mar Biol 38:59-69

Phillips DJH (1980) Quantitative aquatıc bıological indicators. Applied Science Publishers, London

Regoli F, Orlando E (1994) Accumulation and subcellular distribution of metals ( $\mathrm{Cu}, \mathrm{Fe}, \mathrm{Mn}, \mathrm{Pb}$ and $\mathrm{Zn}$ ) in the Mediterranean mussel Mytlus galloprovincialis during a field transplant experiment. Mar Pollut Bull 28:592-600

Reinfelder JR, Fisher NS (1991) The assimilation of elements ingested by marine copepods. Science 251:794-796

Reinfelder JR, Fisher NS (1994) The assimilation of elements ingested by marine planktonic bivalve larvae. Limnol Oceanogr 39:12-20

Rusgå̉rd HU, Bjørnestad E, Møhlenberg F (1987) Accumulation of cadmium in the mussel Mytilus edulis: kinetics and importance of uptake via food and seawater. Mar Biol 96: 349-353

Smith GJ, Flegal AR (1993) Silver in San Francisco Bay estuarine waters. Estuaries 16.547-558

Sung $W$ (1995) Some observations on surface partitioning of $\mathrm{Cd}, \mathrm{Cu}$, and $\mathrm{Zn}$ in estuaries. Environ Sci Technol 29 : $1303-1312$

Tessier A, Couillard Y, Campbell PGC, Auclarr CA (1993) Modeling $\mathrm{Cd}$ partitionung in oxic lake sediments and $\mathrm{Cd}$ concentrations in the freshwater bivalve Anodonta grandis. Limnol Oceanogr 38:1-17

Thomann RV (1981) Equilibrium model of fate of microcontaminants in diverse aquatic food chains. Can J Fish Aquat Sci 38:280-296

Thomann RV, Mahony JD, Mueller R (1995) Steady-state model of biota sediment accumulation factor for metals in two marine bivalves. Environ Toxicol Chem 14:1989-1998

Turner DR, Whitfield M. Dickson AG (1981) The equilibrium speciation of dissolved components in freshwater and seawater at $25^{\circ} \mathrm{C}$ and $1 \mathrm{~atm}$ pressure. Geochim Cosmochim Acta 45:855-881

Valette-Silver NJ, Lauenstein GG (1995) Radionuclide concentrations in bivalves collected along the coastal United States. Mar Pollut Bull 30:320-331

Van Weers AW (1973) Uptake and loss of ${ }^{65} \mathrm{Zn}$ and ${ }^{60} \mathrm{Co}$ by the mussel Mytilus edulis L. In: IAEA (ed) Proc Symp radioactive contamination of the marine environment. IAEA, Vienna, p 385-401

Wang WX, Fisher NS (1996a) Assimilation of trace elements and carbon by the mussel Mytilus edulis: effects of food composition. Limnol Oceanogr 41:197-207

Wang WX, Fisher NS (1996b) Assimilation of trace elements by the mussel, Mytilus edulis: effects of diatom chemical composition. Mar Biol 125:715-724

Wang WX, Fisher NS, Luoma SN (1995) Assimilation of trace elements ingested by the mussel, Mytilus edulis: effects of algal food abundance. Mar Ecol Prog Ser 129:165-176

Whitehead NE, Ballestra S, Holm E, Huynh-Ngoc L (1988) Chernobyl radionuclides in shellfish. J Environ Radioact 7 : 107-121

Widdows $J$ (1985) The effects of fluctuating and abrupt changes in salinity on the performance of Mytilus edulis. In: Gray JS, Christiansen ME (eds) Marine biology of polar regions and effects of stress on marine organism. John Wiley \& Sons, New York, p 555-566

Widdows J, Donkin P, Brinsley MD, Evans SV, Salkeld PN, Franklin A, Law RJ, Waldock MJ (1995) Scope for growth and contaminant levels in North Sea mussels Mytilus edulis. Mar Ecol Prog Ser 127:131-148

Widdows J, Fieth P. Worrall CM (1979) Relationship between seston, available food and feeding activity in the common mussel Mytilus edulis. Mar Biol 50:195-207

Widdows J, Hawkins AJS (1989) Partitioning of rate of heat dissipation by Mytilus edulis into maintenance, feeding, and growth components. Physiol Zool 62:764-784

Wood TM. Baptista AM, Kuwabara JS, Flegal AR (1995) Diagnostic modeling of trace metal partitioning in south San Francisco Bay. Limnol Oceanogr 40:345-358

Wrench JJ (1978) Selenium metabolism in the marine phytoplankters Tetraselmis tetrathela and Dunaliella minuta. Mar Biol 49:231-236

Wright DA (1995) Trace metal and major ion interactions in aquatic animals. Mar Pollut Bull 31:8-18

Wright DA, Zamuda CD (1987) Copper accumulation by two bivalve molluscs: salinity effect is independent of cupric ion activity. Mar Environ Res 23: 1-14

Young DR, Folsom TR (1967) Loss of Zn-65 from the California sea mussel Mytrlus californians. Biol Bull 133:438-447

Zamuda CD, Wright DA, Smucker RA (1985) The importance of dissolved organic compounds in the accumulation of copper by the American oyster, Crassostrea virginica. Mar Environ Res 16:1-12

Zhang GH, Hu MH, Huang YP. Harrison PJ (1990) Se uptake and accumulation in marine phytoplankton and transfer of Se to the clam Puditapes philippinarum. Mar Environ Res 30: $179-190$

Manuscript first recelved: February 14, 1996

Revised version accepted: May 21, 1996 